Research Report No. 15/2008

\title{
New Governance' in European Corporate Law Regulation as Transnational Legal Pluralism
}

Peer Zumbansen

Osgoode Hall Law School of York University, PZumbansen@osgoode.yorku.ca

Follow this and additional works at: http://digitalcommons.osgoode.yorku.ca/clpe

\section{Recommended Citation}

Zumbansen, Peer, "New Governance' in European Corporate Law Regulation as Transnational Legal Pluralism" (2008). Comparative Research in Law \& Political Economy. Research Paper No. 15/2008.

http://digitalcommons.osgoode.yorku.ca/clpe/188 


\section{Comparative Research in Law \& Political Economy}

\section{Peer Zumbansen \\ 'New Governance' in European Corporate Law Regulation as Transnational Legal Pluralism}

Forthcoming in 14 EUROPEAN LAW J OURNAL (2008)

EDITORS: Peer Zumbansen (Osgoode Hall Law School, Toronto, Director, Comparative Research in Law and Political Economy, York University), J ohn W. Cioffi (University of California at Riverside), Lindsay Krauss (Osgoode Hall Law School, Toronto, Production Editor)

This paper can be downloaded without charge from the Social Science Research Network Electronic Library at: http:// ssrn. com/ abstractid=1128145 

CLPE Research Paper 15/2008

Vol. 04 No. 03 (2008)

\title{
Peer Zumbansen
}

\section{'NEW GOVERNANCE' IN EUROPEAN CORPORATE LAW Regulation as Transnational Legal PluRalism}

Forthcoming in 14 EUROPEAN LAW JOURNAL (2008)

\begin{abstract}
The present transformation of European corporate governance regulation mirrors the challenges that have been facing the EU's continuously evolving polity, marked by tensions between centralized integration programs on the one hand and Member State's embedded capitalisms, path-dependencies and rent-seeking on the other. As longstanding concerns with remaining obstacles to more mobility for workers, services, business entities and capital in recent years are aligned with post-Lisbon commitments to creating the World's leading competitive market, European corporate governance regulation [ECGR] has become exposed to and implicated in a set of highly dynamic regulatory experiments. In this context, 'New Governance' offers itself as both tentative label and immodest proposal for a more responsive and innovative approach to European law making. The following paper assesses the recently emerging regulatory forms in ECGR as illustrations of far-reaching transformations in market governance. The arguable parallels between the EU's regulatory transformation in response to growing legitimacy concerns and the recurring question about whose interests a business corporation is intended to serve, provide the framework for an exploration of current regulatory trajectories in European corporate law that can most adequately be understood as a telling example of transnational legal pluralism.
\end{abstract}

Keywords: European Corporate Law, Legal Pluralism, New Governance, Experimentalist Governance, Transnational Law, Executive Compensation

JEL classification: G34, K22, K33 
Peer Zumbansen

Associate Dean (Research, Graduate Studies \& Institutional Relations).

Director, Critical Research Laboratory in Law \& Society

[www.criticalresearchlab.org]; Co-Editor in Chief, German Law Journal

[www.germanlawjournal.com]

Osgoode Hall Law School, York University, Toronto ON

Email: pzumbansen@osgoode.yorku.ca 


\section{'NEW GOVERNANCE' IN EUROPEAN CORPORATE LAW REgULATION AS TRANSNATIONAL LEGAL PluRalism}

Peer Zumbansen*

\section{EUROPEAN CORPORATE GOVERNANCE REGULATION: EMBEDDEDNESS AND CO-EVOLUTION}

The European Commission's corporate governance agenda occupies a unique place within the European imagination. Since the beginning, the 'European company law scene' occupied regulators and policy makers inside and outside of Europe, and recent innovations and changes in the approaches to regulatory governance have given this area a set of noteworthy turns. The arrival of 'new governance' in the area of European Corporate Governance Regulation [ECGR] brings the already charged interests and dynamics that are at stake in this area, into much sharper contours. New Governance [NG] is itself a label for a tremendously challenging and provoking trajectory for the EU's transnational governance. Ever since 'governance' entered the scene through the Commission's 'White Paper on European Governance' in 2001', the spectre of a fundamental transition from government to governance has

\footnotetext{
* Canada Research Chair in the Transnational and Comparative Law of Corporate Governance at Osgoode Hall Law School, York University, Toronto. He is Founder/Director of Critical Research Laboratory in Law \& Society [www.criticalresearchlab.org] at Osgoode and Regular Visiting Professor at the Collaborative Research Centre "Transformations of the State" in Bremen (http://www.sfb597.uni-bremen.de/). Email: Pzumbansen@osgoode.yorku.ca. Thanks to Simon Archer, Farzana Nawaz, Fenner Kennedy-Stewart and Phillip Bevans for their helpful comments. Paul Hancock, Stephen Wolpert, Zohar Levy and Hermie Abraham at Osgoode Hall provided excellent research assistance. Financial support from the Social Sciences and Humanities Research Council of Canada (SSHRC, Grant \# 410-2005-2421) is gratefully acknowledged. Errors remain mine.

1 “European Governance. A White PAPer” [COM(2001) 428 final], dated 25 July 2001, available at: http://eurlex.europa.eu/LexyUriServ/site/en/com/2001/2001/com2001_0428en01.pdf (last visited 7 April 2008).
} 
been haunting Europe ${ }^{2}$, as well as transnational regulatory spheres. ${ }^{3}$ The Commission's definition of governance as 'a very versatile one [...] being used in connection with several contemporary social sciences, especially economics and political science', and as one originating 'from the need of economics (as regards corporate governance) and political science (as regards State governance) for an all-embracing concept capable of conveying diverse meanings not covered by the traditional term "government", 4 is very open-ended and leaves one wondering whether the definition is meant to conclude or open an inquiry into the changing nature of market regulation. ${ }^{5}$

Without intending to overly strain the Commission's reference to corporate governance in the cited definition, the following observations will nevertheless point to particular complementarities between the EU's ongoing construction process and the unfolding European Corporate Governance Matrix. The varied history of European corporate law regulation is marked by the diversity of interests and concerns invested in this area of regulation. While the legislative record was, until recently, not altogether comprehensive ${ }^{6}$, ECGR has in the last years become one of the

${ }^{2}$ See F. W. Scharpf, Governing Europe. Effective and Democratic? (Oxford University Press, 1999), the contributions in C. Joerges/Y. Mény/J. H. H. Weiler (eds.), Mountain or Molehill? A Critical Appraisal on the Commission White Paper on Governance (Harvard Law School Jean Monnet Working Paper No.6/01, 2001), and the analysis by D.

Trubek/L. G. Trubek, 'Hard and Soft Law in the Construction of Social Europe: the Role of the Open Method of Coordination', (2005) 11 European Law Journal 343-364.

${ }^{3}$ See e.g. A.-M. Slaughter, 'Disaggregated Sovereignty: Towards the Public Accountability of Global Government Networks', (2004) 39 Government and Opposition 159-190.

${ }^{4}$ European Commission: 'GOVERNANCE', available at: http://ec.europa.eu/governance/index_en.htm (last visited 7 April 2008)

${ }^{5}$ Hereto, see C. Möllers, 'European Governance: Meaning and Value of a Concept', (2006) 43 Common Market Law Review 313-336 (for a scathing critique of the omnipresent resorting to a still poorly defined and demarcated concept).

${ }^{6}$ For an overview of the legislative acts in the area of company law up to 2000, see J. Wouters, 'European Company Law: Quo Vadis?' (2000) 37 Common Market Law Review 257-307, and V. Edwards, EC Company Law (Oxford University Press, 1999); for a more recent discussion of state and prospects of EC company law making, see K. J. Hopt, 'European Company Law and Corporate Governance: Where does the Action Plan of the European Commission Lead?' in K. J. Hopt,E. Wymeersch,H. Kanda and H. Baum (eds.), 
most vibrant sectors of norm-creation and regulatory interaction. As such, ECGR has become a regulatory universe of its own, with a large portfolio within the Commission's Internal Market division and a seemingly tireless expert community feeding into the policy and norm making process at every turn. With ECGR long having left the confines of the European Court of Justice, the Council and Parliament, it has expanded into an extremely versatile, comparative and transnational legal field. ECGR constitutes a semi-autonomous field, comprised both of hard law and social norms, which are in a constant relation of complementarity, fusion and irritation. ${ }^{7}$ As such ECGR presents formidable challenges for legal, economic, sociological or political analysis. From the point of view of legal pluralism, the particularity and intricacy of ECGR lies in its mixed constitution of law and 'social norms'. 8 Seen through the legal pluralist lens, ECGR develops as a co-evolutionary process, where the imposition of law - which encompasses regulations, directives, recommendations and judgments - is both shaping and being shaped by the norms evolving outside of its imposition. Similar to the unpredictability of consequences and effects of rights/principles-transplants ${ }^{9}$, ECGR faces enormous

Corporate Governance in Context (Oxford University Press, 2005); for a continuously updated listing of directives, regulations and recommendations, see the website of the European Commission at http://ec.europa.eu/internal_market/company/index_en.htm (last visited 5 April 2008)

${ }^{7}$ S. F. Moore, 'Law and Social Change: the semi-autonomous field as an appropriate subject of study', (1973) 7 Law \& Society Review 719-746; G. Teubner, 'Eigensinnige Produktionsregimes: Zur Ko-evolution von Wirtschaft und Recht in den varieties of capitalism', (1999) 5 Soziale Systeme 7-25

${ }^{8}$ P. Zumbansen, 'Spaces and Places: A Systems Theory Approach to Regulatory Competition in European Company Law', (2006) 12 Eur. L. J. 534-556; see generally S. E. Merry, 'Legal Pluralism', (1988) 22 Law \& Society Review 869-901; H. W. Arthurs/C. Mummé, 'From Governance To Political Economy: Workers As Citizens, Stakeholders and Productive Social Actors. Paper for the First International CLPE Conference: The Corporate Governance Matrix: Unfolding the New Agenda, Osgoode Hall Law School, Toronto, 20-21 October 2005', (2005) CLPE Research Paper Series (www.comparativeresearch.net) , published in (2007) 45 Osgoode Hall Law Journal 439470

${ }^{9}$ G. Teubner, 'Legal Irritants: How Unifying Law Ends Up In New Divergences', in P. A. Hall and D. Soskice (eds.), Varieties of Capitalism. The Institutional Foundations of Comparative Advantage (Oxford University Press, 2001); K. Pistor, 'Of Legal Transplants, Legal Irritants, and Economic Development', in P. Cornelius and B. Kogut 
challenges in terms of legal certainty and strategy, given its many sources of potential disturbance, irritation, and complementing points due to its complex regulatory agenda. With view to the challenges facing the EU from the substantive enlargement in 2004, Silvana Sciarra observed: 'As the tradition of comparative legal scholarship in Europe has taught us, the attempt to pursue a "transplant" of legal institutions uncritically is both a sign of disregard for traditions different from the one to be transplanted, and, very often, is an inefficient solution., 10

Adding to the difficulties arising from the multilevel and multi-stakeholder dimension in company law regulation in Europe, ECGR has been amplifying the tensions that underlie the conceptual and architectural distinction between 'company' and 'capital market' law, which are deeply embedded in a country's market Regulation histories. ${ }^{11}$ Struggling with competing policy goals regarding the enhancement of market freedoms as they relate to capital market rules on the one hand and to corporate governance law on the other, ECGR is driven to actualize 'the best of both worlds'. Yet, while corporate law itself appears to continue to withstand all attempts at deconstruction and demystification by other conceptual

(eds.), Corporate Governance and Capital Flows in a Global Economy (Oxford University Press, 2003).

${ }^{10}$ S. Sciarra, 'The Convergence of European Labour and Social Rights: Opening to the Open Method of Coordination', in G. A. Bermann and K. Pistor (eds.), Law and Governance in an Enlarged European Union (Hart Publishing, 2004), 155 (with reference to Kahn-Freund, (1974) 37 Modern Law Review 1)

${ }^{11}$ R. Wiethölter, Interessen und Organisation der Aktiengesellschaft im amerikanischen und deutschen Recht (C. F. Müller, 1961); R. Buxbaum/K. J. Hopt, Legal Harmonization and the Business Enterprise. Corporate and Capital Market Law Harmonization Policy in Europe and the U.S.A. (Walter de Gruyter, 1988); F. Kübler, 'The Impact of Equity Markets on Business Organization: Some Comparative Observations Regarding Differences in the Evolution of Corporate Structures', (2001) 2 European Business Organization Law Review [EBOR] 669-683; H. Merkt, 'Zum Verhältnis von Kapitalmarktrecht und Gesellschaftsrecht in der Diskussion um die Corporate Governance', (2003) 48 AG 126-136; H. Eidenmüller, 'Forschungsperspektiven im Unternehmensrecht', (2007) 62 Juristenzeitung [JZ] 487-494; N. Moloney, 'New Frontiers in EC Capital Markets Law: From Market Construction to Market Regulation', (2003) 40 Common Market Law Review 809-843; for the U.S., see only R. Romano, 'The Sarbanes-Oxley Act and the Making of Quack Corporate Governance', (2005) 114 Yale L. J. 1521-1611 
frameworks as to what corporations $\mathrm{do}^{12}$, ECGR finds itself deeply involved in a large, ever-so amorphous market-building project. The 'function' of the firm, as necessarily implicated within ECGR, must now extend far beyond the financial-organisational dimensions that have recently again been depicted as the 'what', 'how' and 'why' of corporate law. Within the European project, in particular after the Lisbon Summit $2000^{13}$ and its most recent reinvigoration in form of a 'social makeover', corporate law has become a strategic token in a complex multilevel governance game that brings a much wider range of players to the policymaking table than any single Market regulation unit would reasonably want to assume responsibility for.

While the to-do-list for ECGR, only seems to keep growing in view of pressing competitive, social, environmental and monitoring demands ${ }^{15}$, it has in fact always been evolving in a particularly accentuated and contested field of contrasting and competing Member State agendas in pursuit of national prosperity, of which corporate and capital market law

12 See only Robert C. Clark, Corporate Law (Little Brown, 1986), at 5 (regarding the importance of incorporating labour law into one's study of business corporations); but see R. Kraakman/P. L. Davies/H. Hansmann/G. Hertig/K. J. Hopt/H. Kanda/E. B. Rock, The Anatomy of Corporate Law. A Comparative and Functional Approach (Oxford University Press, 2004)

13

'THE LisBon SPECIAL EUROPEAN COUNCIL (MARCH 2000): TOWARDS A EUROPE OF INNOVATION AND KNOWLEDGE’ (HTTP://EUROPA.EU/SCADPLUS/LEG/EN/CHA/C10241.HTM) (LAST VISITED 5 APRIL 2008)

${ }^{14}$ Euractiv: Lisbon Agenda gets social makeover (18 March 2008), reporting on the 1314 March 2008 Summit's recommendations to move away from its purely "growth and jobs" focus of the past three years and to put the environment and citizens more "in the foreground” (http://www.euractiv.com/en/innovation/eu-lisbon-agenda-gets-socialmakeover/article-171013) (last visited 5 April 2008)

${ }^{15}$ See the Commission's Action Plan of 2003 “MODERNISING COMPANY LAW AND ENHANCING CORPORATE GOVERNANCE IN THE EUROPEAN UNION - A PLAN TO MOVE FORWARD” [COM (2003) 284 Final]; see also the Director General's for Internal Market and Services' Summary Report of 2007 on the "Consultation and Hearing on Future Priorities on the Action Plan [...]”; on the tasks lying ahead, see K. J. Hopt, 'European Company Law and Corporate Governance: Where does the Action Plan of the European Commission Lead?' in K. J. Hopt,E. Wymeersch,H. Kanda and H. Baum (eds.), Corporate Governance in Context (Oxford University Press, 2005). 
had always been a central building block. ${ }^{16}$ As such, ECGR has never sat comfortably within the wider market integration agenda. The real challenges of company law harmonization, however, became impressively obvious during the exhausting struggle over the adoption of a regulation concerning the creation of the European Company statute, originally initiated already in the 1970s, and eventually passed after many more compromises, in 2001. ${ }^{17}$ Another illustration of how ECGR has been inextricably caught up in the European 'Varieties of Capitalism' ${ }^{\text {,8 }}$ was, without doubt, the long contest over a European Takeover Directive ${ }^{19}$, which resulted in 2004 in a Directive full of loop-holes and opt-out clauses. ${ }^{20}$ Eddy Wymeersch recently called the moment of adopting the Directive a 'provisional semi-final point in a process that has taken more than 17 years, and according to some even more than 30 years on the way

${ }^{16} \mathrm{~J}$. W. Cioffi/S. S. Cohen, 'The state, law and corporate governance: the advantage of forwardness', in S. S. Cohen and G. Boyd (eds.), Corporate Governance and Globalization. Long Range Planning Issues (Edward Elgar, 2000)

${ }^{17}$ E. Werlauff, 'The SE Company - A New Common European Company from 8 October 2004', (2003) 14 European Business Law Review [EBLR] 85-103; C. Teichmann, 'The European Company - A Challenge to Academics, Legislatures and Practitioners', (2003) 4 German L. J. 309-330

${ }^{18}$ P. A. Hall/D. Soskice (eds.), Varieties of Capitalism. The Institutional Foundations of Comparative Advantage (Oxford University Press, 2001)

${ }^{19}$ See R. J. Gilson, 'The Political Ecology of Takeovers: Thoughts on Harmonizing the European Corporate Governance Environment', in K. J. Hopt and E. Wymeersch (eds.), European Takeovers. Law and Practice (Butterworths, 1992), and E. Wymeersch, 'Problems of the Regulation of Takeover Bids in Western Europe: A Comparative Survey', in K. J. Hopt and E. Wymeersch (eds.), European Takeovers. Law and Practice (Butterworths, 1992).

${ }^{20}$ For the history, see C. Kirchner/R. W. Painter, 'Takeover Defenses under Delaware Law, the Proposed Thirteenth EU Directive and the New German Takeover Law: Comparison and Recommendations for Reform', (2002) 50 American Journal of Comparative Law 451-476; P. Zumbansen, 'European Corporate Law and National Divergences: The Case of Takeover Law', (2004) 3 Wash. U. Glob. Stud. L. Rev. 867886; for a recent analysis, see Blanaid Clarke, 'Takeover Regulation: Through the Looking Glass', (2007) CLPE Comparative Research in Law \& Political Economy Research Paper No. 18, available at: www.comparativeresearch.net/papers.jsp; for a USUK comparative perspective, see John Armour \& David Skeel Jr., 'Who Writes the Rules for Hostile Takeovers, and Why? - The Peculiar Divergence of U.S. and U.K. Takeover Regulation', (2007) Georgetown L. J. 1727-1794. 
to opening up the European markets for corporate control. ${ }^{\text {,21 }}$ At the time, André Nilsen observed that '[T]he Takeover Directive sees light after a long and acrimonious journey through the institutional labyrinth in Brussels. $^{22}$

As the regulatory trajectory of ECGR continues to unfold, we must be even more sensitive to the degree to which this enterprise remains deeply embedded in the particular dynamics of multilevel governance of European integration on the one hand ${ }^{23}$ and the globalization of markets and regulatory processes on the other. ${ }^{24}$ Under such conditions, an assessment of the concrete forms of norm-creation presents great challenges due to ECGR's complex appearances ranging from 'hard' to 'soft' law to norms that are developed, promulgated and disseminated by a panoply of public and private actors. ${ }^{25}$ Therefore, instead of trying to free ECGR from its embeddedness in this complex regulatory environment, the emphasis must be on the exact opposite. Precisely by embracing the embeddedness of ECGR as a transnational legal field can we begin to

${ }^{21}$ Eddy Wymeersch, ‘The Takeover Bid Directive, Light and Darkness', (January 2008)

Financial Law Institute Working Paper No. 2008-01, available at http://ssrn.com/abstract=1086987, at 2

${ }^{22}$ A. Nilsen, 'The EU Takeover Directive and the Competitiveness of European Industry', (2004) The Oxford Council on Good Governance http://www.oxfordgovernance.org/fileadmin/Publications/EY001.pdf

${ }^{23}$ See M. Jachtenfuchs, 'The Governance Approach to European Integration', (2001) 39 Journal of Common Market Studies 245-264; I. Bache/M. Flinders (eds.), Multi-level Governance (Oxford University Press, 2004); but see now C. F. Sabel/J. Zeitlin, 'Learning from Difference: The New Architecture of Experimentalist Governance in the EU', (2008) 14 European L.J. 271-327.

${ }^{24}$ See e.g. D. Rodrik, 'Governance of Economic Globalization', in J. S. Nye and J. D. Donahue (eds.), Governance in a Globalizing World (Brookings, 2000); David S. Law, 'Globalization and the Future of Constitutional Rights', (2008) Nw. U. L. Rev. 1-82, at 31: 'Although globalization appears to have levelled off in the world's wealthiest countries in recent years - and the "social" component, in particular, now lags behind the "economic" and the "political" components - the overall trend across all countries remains one of increasing globalization.'

${ }^{25}$ For a succinct account of this regulatory development, see D. Trubek/L. G. Trubek, 'Hard and Soft Law in the Construction of Social Europe: the Role of the Open Method of Coordination', (2005) 11 European Law Journal 343-364. 
better see the concrete as well as the amorphous forms of change. Embeddedness is here understood in the following four dimensions:

a) ECGR is informed by the policy and legislative dynamics between corporate law and capital-market law (securities regulation) as well as between corporate law and labour law, categorizations of functionally separable legal areas that can be found in all advanced industrialized societies and that are increasingly challenged through global forces of rule-making;

b) ECGR is entangled in the European 'Varieties of Capitalism' with regard to corporate and labour regulation, as evidenced for example in the struggle over the Takeover Directive and the statute of the Societas Europaea;

c) ECGR as part of the larger project towards the completion of the European internal market ${ }^{26}$, in particular in the post-Lisbon environment of knowledge society politics within the $\mathrm{EU}^{27}$

d) ECGR as semi-autonomous field, marked by a vibrant and yet precarious, always threatened balance between official law making, transnational consultations, expert committee preparatory work, recommendations, communications and standardization, that we see unfolding on the domestic, EU-supranational and transnational level.

The following section (II) will further draw out the correlations between the ECGR and the unfolding forms of 'new' and 'experimental' governance forms in the EU. Section III will work out the connections

${ }^{26}$ C. Barnard/S. Deakin, 'Market Access and Regulatory Competition', in C. Barnard and J. Scott (eds.), The Law of the Single European Market. Unpacking the Premises (Hart Publishing, 2002)

${ }^{27}$ See the Presidency Conclusions of the Council of the European Union [7652/08], March 13-14, 2008, available at: http://www.consilium.europa.eu/ueDocs/cms_Data/docs/pressData/en/ec/99410.pdf, at 4: 'The implementation of the broad-based innovation strategy is key to realising EU ambitions in the area.' For an intriguing historical background, see Dominique Pestre, Science, Society and Politics. Knowledge Societies from an Historical Perspective. Report to the Science, Economy and Society Directorate, European Commission, January 2007, available at: http://ec.europa.eu/research/sciencesociety/document_library/pdf_06/historical-perspectives_en.pdf. 
between the transnational pluralism of ECGR and emerging, parallel forms of transnational norm-creation by focusing on the disclosure of executive compensation. The emergence of de-territorialized, hybrid regulatory regimes, consisting of both hard and soft norms governing particular elements of corporate governance accentuates the degree to which ECGR has come under pressure to facilitate quasi-neutral, 'best' practices in 'good' corporate governance. This functionalist 'normalisation' of corporate governance standards illustrates, in turn, how the European Company Law scene ${ }^{28}$ sees itself increasingly transnationalized. As a result, corporate governance regulation presents formidable challenges with view to developing adequate enabling rules for corporate actors in highly competitive global markets while not frustrating critics' attempts at preventing the insulation of emerging regulatory processes from outside assessment. The paper will suggest that a combination of 'reflexive corporate governance' and 'transnational legal pluralism' can best capture this new regulatory challenge. With this body of law constituting an intricate combination of both substantive and procedural aspects, evolving intertwined processes of law/norms negotiation, dissemination and alternative 'enforcement' modes, ECGR goes beyond and reaches across categories through which comparative company law scholars have been assessing the function of the corporation $^{29}$ and the rules governing its behaviour. ${ }^{30}$ Part IV concludes.

${ }^{28}$ C. Schmitthoff, 'The Future of the European Company Law Scene', in C. Schmitthoff (eds.), The Harmonisation of European Company Law (The U.K. Nat'l. Committee of Comparative Law, 1973)

${ }^{29}$ R. Kraakman/P. L. Davies/H. Hansmann/G. Hertig/K. J. Hopt/H. Kanda/E. B. Rock, The Anatomy of Corporate Law. A Comparative and Functional Approach (Oxford University Press, 2004)

${ }^{30}$ La Porta R., Lopez-de-Silanes F., Shleifer A. and Vishny R. 'Law and finance', (1998) Journal of Political Economy, 106: 1113-1155; La Porta R., Lopez-de-Silanes F., and Shleifer A. (2007) 'The economic consequences of legal origins' available at SSRN (http://ssrn.com/abstract=1028081), (2007) Journal of Economic Literature forthcoming; see the critique by Simon Deakin, 'Corporate Governance and Human Development', Tanner Lectures presented at the University of Oxford, February 2008, ms. on file with author; B. Ahlering/S. Deakin, 'Labor Regulation, Corporate Governance, and Legal Origin: A Case of Institutional Complementarity?' (2007) 41 Law \& Society Rev. 865903; Roe, M. (2006) ‘Legal origins, politics and modern stock markets’ (2006) 120 Harvard Law Review, 460-527; M.Siems, 'Shareholder protection around the world (“Leximetric II”)', (2008) Delaware Journal of Corporate Law, forthcoming 
[VOL. 04 No. 03

\section{II. 'NEW' AND 'EXPERIMENTALIST GOVERNANCE' IN EUROPEAN CORPORATE LAW REGULATION: Towards Transnational Legal PluRAlism}

\section{A. ECGR BETWEEN HARMONIZATION AND REgUlATORY COMPETITION}

Any assessment of emerging forms of corporate governance regulation in Europe has to build on the fast-growing body of scholarship by legal sociology and conflicts of laws scholars ${ }^{31}$ on the one hand and comparative company law experts on the other. ${ }^{32}$ The present challenge in facilitating a mutually enriching dialogue and exchange between this scholarship and the ongoing exploration of EU governance, which remains - due to its complexity of levels and contexts of regulation - for the most part a domain almost exclusively gardened by EU-focused regulatory theorists. One important area of 'overlap' between EU regulatory work and Corporate Governance scholarship is marked by the tension between harmonization and regulatory competition. This perspective has for years been informing a fruitful comparative inquiry into the different conditions in particular between the U.S. federal organisation of corporate law making (states) and securities regulation (federal). ${ }^{33}$ Recent years have

\footnotetext{
${ }^{31}$ See e.g. A. Riles, 'A New Agenda for the Cultural Study of Law: Taking on the Technicalities', (2005) 53 Buffalo L. Rev. 973; R. Michaels, 'The Re-State-Ment of NonState Law: The State, Choice of Law, and the Challenge from Global Legal Pluralism', (2005) 51 Wayne L. Rev. 1209-1259; R. Michaels, 'The True New Lex Mercatoria: Law Beyond the State', (2007) 14 Ind. J. Glob. Leg. Stud. 447-468; P. Schiff Berman, 'Global Legal Pluralism', (2007) 80 S. Cal. L. Rev. 1155-1237

${ }^{32}$ See e.g. K. J. Hopt/P. C. Leyens, 'Board Models in Europe. Recent Developments of Internal Corporate Governance Structures in Germany, the United Kingdom, France and Italy. ECGI Law Working Paper No. 18/2004', in: 2004 available at: http://ssrn.com/abstract=487944;

${ }^{33}$ See only R. Buxbaum, 'Federal Aspects of Corporate Law and Theory', in T. Daintith and G. Teubner (eds.), Contract and Organisation. Legal Analysis in the Light of Economic and Social Theory (Walter de Gruyter, 1986), and D. Charny, 'Competition among Jurisdictions in Formulating Corporate Rules: An American Perspective on the "Race to the Bottom" in the European Communities', (1991) 32 Harvard International Law Journal (Harv. Int'l L.J.) 423-456.
} 
seen significant process in reaching beyond the obvious obstacles to comparisons by focusing, on the one hand, more clearly on the evolving flexible and hybrid forms of regulation in Europe ${ }^{34}$ and, on the other, by sophisticating the underlying comparative methodologies. ${ }^{35}$ Again, the emphasis on the paradoxical nature of the emerging regulatory forms as being both embedded in learned regulatory practices from within the Member States and disembedded in terms of evolving within a dramatically globalising market points to the difficulties of disentangling any assessment of ECGR from the larger project of European integration ${ }^{36}$ which is itself inescapably and always tied to processes of globalization of capital, labour, and rights.

It is against this background that the particular challenges facing ECGR can best be illustrated, by studying them through the lens of transnational law and, more specifically, through the emerging prism of transnational legal pluralism. The connection of observations of the transformation of public and private international law towards 'transnational law' ${ }^{37}$ and the legal-sociological and anthropological work on legal pluralism offers important insights into a better understanding of current trajectories of functionally determined regulatory areas. ECGR is a powerful illustration of such a functional field, determined both by its semi-autonomous nature with regard to its tension between law/norms and politics/market. The latter are powerfully evident in ECGR, which emerges through the co-

\footnotetext{
${ }^{34}$ S. Deakin, 'Regulatory Competition versus Reflexive Harmonisation in European Company Law', in D. C. Esty and D. Geradin (eds.), Regulatory Competition and Economic Integration. Comparative Perspectives (Oxford University Press, 2001); J. Armour, 'Who Should Make Corporate Law? EC Legislation versus Regulatory Competition', (2005) 55 Curr. Leg. Probls. 369-413; G. Hertig/J. A. McCahery, 'Optional rather than Mandatory EU Company Law: Framework and Specific Proposals', (2007) European Company and Financial Law Review [ECFR] 341-362

${ }^{35}$ See David C. Donald, ‘Approaching Comparative Company Law’, (2008) Fordham J. Corp. \& Fin. L. forthcoming, available at http://papers.ssrn.com/sol3/papers.cfm?abstract_id=1092452; K-J Hopt, 'Comparative Company Law’, in: (2006) Mathias Reimann \& Reinhard Zimmermann eds., Oxford Handbook of Comparative Law 1161-1191.

${ }^{36}$ P. Zumbansen, 'Spaces and Places: A Systems Theory Approach to Regulatory Competition in European Company Law', (2006) 12 Eur. L. J. 534-556

${ }^{37}$ P. C. Jessup, Transnational Law (Yale University Press, 1956)
} 
evolution of the different functional dynamics, which drive corporate organisation. At the same time, the fast-emerging forms of new corporate organisation such as private equity vehicles and hedge funds seem to defy an organisation-oriented assessment of the firm in favour of a differently positioned analysis of contemporary corporate forms. As the 'end-ofhistory' thesis in comparative corporate governance scholarship and the Berle-Means paradigm of corporate organisation and its related governance issues are revisited and recontextualised ${ }^{38}$, the dramatic threat of a mortgage-loan meltdown in the spring of 2008 points to the need of a comprehensive reassessment of the corporate governance approach for an understanding of the financial structures of the corporate form and the contested aspiration of financial markets regulation. ${ }^{39}$

\section{B. The Polarities of EU Governance: Global COMPETITIVENESS, INDIRECT REGULATION AND 'REFLEXIVE CORPORATE GOVERNANCE’}

Recent ECGR developments must be seen in the context of a highly diversified series of norm-setting processes resulting in a veritable explosion of corporate governance codes in Europe and elsewhere. ${ }^{40}$ With the proliferation of corporate governance codes, influenced and pushed by international $^{41}$ and transnational activities of norm setting, discussion and thought exchange ${ }^{42}$, it has become increasingly difficult to identify a

\footnotetext{
${ }^{38}$ See W. W. Bratton/M. L. Wachter, Shareholder Primacy's Corporatist Origins: Adolf Berle and The Modern Corporation, available at http://ssrn.com/abstract $=1021273$ 2007); D. Tsuk, 'From Pluralism to Individualism: Berle and Means and 20th Century American Legal Thought', (2005) 30 Law \& Soc. Inquiry 179-225.

${ }^{39}$ Marcel Kahan/Edward B. Rock, 'Hedge Fund Activism in the Enforcement of Bondholder Rights', NYU Law and Economics Research Paper No. 08-02, available at: http://ssrn.com/abstract=1093387; see already Sanford Jacoby, 'Finance and Labor: Perspectives on Risk, Inequality, and Democracy’, (2008), available at http://ssrn.com/abstract $=1020843$

40 See the list of codes in various countries at www.ecgi.org. $\mathrm{s}$

${ }^{41}$ OECD; WCFCG; IVCGN

${ }^{42}$ ECGI, INSEAD, Euroshareholders etc.
} 
single institution or author of a set of norms. Instead, the production and dissemination of corporate governance rules has for some time now taken on the nature of migrating standards ${ }^{43}$ and a cross-fertilization of norms is now regarded as eminent and necessary in shaping future corporate activity. A distinct feature of this de-territorialized production of norms is the radical challenge these processes pose for our understanding of what we call law proper. With the dissemination of corporate governance codes, disclosure standards and rules, best practices and codes of conduct, not only corporate and securities law, but also other fields of law - such as labour and employment law - change. The decentralization of norm producers is repeated, mirrored and reflected in the hybridization of the norms themselves. It is in this sense, that the study of the proliferation of corporate governance codes and company law production in general and of the rules of remuneration disclosure in particular feeds into a broader research into the changing face of legal regulation in globally integrated marketplaces. What shines through particular developments in individual jurisdictions in this regard, is a most poignant exhibition of particular legal and political cultures and political economies of law making and economic regulation. $^{44}$

'New' or alternative modes of governance have been emerging in response and reaction to the regulatory challenges that inevitably arise from these distinct variances in 'Member States' regulatory design. The most remarkable regulatory innovation in recent years is without doubt the socalled Open Method of Coordination [OMC], which, after emerging during the 1990s in the realm of politically contested national, economic and employment policies, had been formally adopted at the 2000 Lisbon Summit. Its defining feature has been the proceduralisation of regulatory governance by benchmarking and disseminating non-binding objectives

43 See for a comparable analysis of migrating human rights standards, C. Scott/R. Wai, 'Transnational Governance of Corporate Conduct through the Migration of Human Rights Norms: The Potential of Transnational "Private" Litigation', in C. Joerges,I.-J. Sand and G. Teubner (eds.), Transnational Governance and Constitutionalism (Hart Publishing, 2004).

${ }^{44}$ P. Zumbansen, 'Spaces and Places: A Systems Theory Approach to Regulatory Competition in European Company Law', (2006) 12 Eur. L. J. 534-556 
and standards across a growing body of regulatory areas. ${ }^{45}$ 'In the years following the Lisbon Summit, the OMC [...] appeared to have become the governance instrument of choice for EU policymaking in complex, domestically sensitive areas, where diversity among the Member States precludes harmonisation but inaction is politically unacceptable, and where widespread strategic uncertainty recommends mutual learning at the national as well as the European level. ${ }^{46}$ The departure of the OMC from the more rigid norm-generation and enforcement program of the 'Community Method' has been both welcomed and criticised. ${ }^{47}$ What Francis Snyder identified as 'the challenge of sites' facing the European Constitutionalist project ${ }^{48}$, indeed constitutes the framework for the proliferating norm-generation processes of ECGR. As we will see in the example of regulating the disclosure requirements for executive compensation, this area of ECGR is marked by a deep, underlying tension between increasingly decentralised, indirect regulatory forms on the one hand and vaguely defined and yet broadly conceived policy goals against which the adequacy and the success of lower-level norm-setting processes will be measured, on the other. At the same time, EU internal corporate governance negotiations are increasingly becoming disembedded from the exclusionary European context as they are complemented, irritated and shaped by those norms and principles ('best practices' and 'guidelines' that are disseminated on the transnational level, promulgated, for example, by actors such as the OECD). ${ }^{49}$

${ }^{45}$ D. Hodson/I. Maher, 'The Open Method as a New Mode of Governance: The Case of Soft Economic Policy Coordination', (2001) 39 Journal of Common Market Studies 719746

${ }^{46}$ C. F. Sabel/J. Zeitlin, 'Learning from Difference: The New Architecture of Experimentalist Governance in the EU', (2008) 14 European L.J. 271-327, at 292

${ }^{47}$ See e.g. J. Scott/D. Trubek, 'Mind the Gap: Law and New Approaches to Governance in the European Union', (2002) 8 European Law Journal 1-18;

${ }^{48}$ F. Snyder, 'European Constitutionalism in the 21st Century', in T. Tridimas and P. Nebbia (eds.), European Union Law for the Twenty-First Century, vol. 1 (Hart Publishing, 2004), at 13

${ }^{49}$ See the OECD Principles of Corporate Governance, rev. 2004, available at http://www.ecgi.org/codes/documents/principles_en_final.pdf. 
Seen, thus, under the magnifying glass, ECGR can be described to unfold as a particular open-ended and contestable practice. ${ }^{50}$ Even a cursory overview of the emerging features of ECGR suggests strong corollaries between ECGR and emerging general forms of 'new' ${ }^{\text {, }}$ ' or 'experimental' EU governance ${ }^{52}$ on the one hand and between ECGR and transnational governance forms in corporate and labour law on the other. ${ }^{53}$

On the 'inside' of the European integration process, recent years have seen a tremendous drive towards the creation of ever-more flexible forms of indirect regulation, benchmarking and rule/standards production through expert groups and advisory committees. As Simon Deakin argues in this issue $^{54}$, expert groups such as the European Corporate Governance Forum $^{55}$, while importantly building on recent experiences with the Winter I and II groups and their vital contribution to break the deadlock over the Takeover Directive, nevertheless reinforce and further accentuate the drive towards a 'right' standard in corporate governance regulation despite the declarations that many years of debating the convergence and divergence of corporate governance standards ${ }^{56}$ should support the view that 'no one size fits all' ${ }^{57}$

\footnotetext{
${ }^{50}$ See N. Reich, Understanding EU Law. Objectives, Principles and Methods of Community Law, 2nd ed. (Intersentia, 2005), 307: 'Governance is concerned with achieving this balance between legitimate and illegitimate uses of autonomy.'

${ }^{51}$ Critically: Scott/Trubek, 'Mind the Gap', supra; see also K. A. Armstrong, 'Rediscovering Civil Society: The European Union and the White Paper on Governance', (2002) 8 European Law Journal 102-132.

52 Sabel/Zeitlin, 'Learning from Difference', supra.

53 P. Zumbansen, 'The Parallel Worlds of Corporate Governance and Labor Law', (2006) 13 Indiana Journal of Global Studies 261-312
}

${ }^{54}$ S. Deakin, 'Reflexive Governance and European Company Law, in: CLPE Research Paper Series 2007', in: available at: www.comparativeresearch.net (in this issue)

${ }^{55}$ See the website at http://ec.europa.eu/internal_market/company/ecgforum/index_en.htm.

\footnotetext{
${ }^{56}$ See e.g. J. N. Gordon, 'Pathways to Corporate Governance ? Two Steps on the Road to Shareholder Capitalism in Germany', (1999) 5 Columbia Journal of European Law 219241; R. J. Gilson, 'Globalizing Corporate Governance: Convergence of Form or Function?' (2001) 49 Am. J. Comp. L. 329-357; E. Wymeersch, 'Convergence or Divergence in Corporate Governance Patterns in Western Europe?' in J. A. McCahery,P.
} 
Paradoxically, the operational method of the OMC, originally designed to promote greater flexibility and pressure to foster a race to the top in social standards, transforms itself in the context of the ECGR into an engine towards 'best practice in corporate governance'. The utilitarian, soft-law approach as here employed, leads to considerably different results than would have been hoped for in other areas of the OMC. With view to the earlier described tensions between different regulatory trajectories of corporate governance - consisting of an amalgamation of company law, securities regulation, taxation and insolvency law - the pursuit of 'best practices' is determined by a considerably narrower scope of functional concerns. At this point, the goals of this pursuit are fused too fast and probably too uncritically with the functional orientation of the post-Lisbon Innovation and Competitiveness Agenda. By emphasizing the need to ensure the economic performance and, connected herewith, the integrity and stability of financial institutions ${ }^{58}$, corporate governance as a regulatory field is taken out of the more complex regulatory context we have seen unfold over the course of the $20^{\text {th }}$ century. ${ }^{59}$

As the globalisation of corporate activity and finance undermines any attempt at effectively re-domesticating corporate governance into the

Moerland,T. Raaijmakers and L. Renneborg (eds.), Corporate Governance Regimes. Convergence and Diversity (Oxford University Press, 2002).

${ }^{57}$ See Frits Bolkestein, Corporate Governance in the Euopean Union, Speech of October 18, 2004 on the occasion of the Inauguration of the ECGF in The Hague, available at: http://europa.eu/rapid/pressReleasesAction.do?reference=SPEECH/04/460\&format=PDF \&aged=1\&language=EN\&guiLanguage=en; See J. Winter, 'Report of the High Level Group of Company Law Experts on A Modern Regulatory Framework for Company Law in Europe', (2002) at http://ec.europa.eu/internal_market/company/docs/modern/report_en.pdf, at 9, 72.

${ }^{58}$ Bolkestein, preceding note

${ }^{59}$ See e.g. A. A. Berle, The 20th Century Capitalist Revolution (Harcourt, Brace \& World, 1954); M. J. Roe, 'Path Dependence, Political Options and Governance Systems', in K. J. Hopt and E. Wymeersch (eds.), Comparative Corporate Governance. Essays and Materials (Walter de Gruyter, 1997); E. Berglöf/E.-L. v. Thadden, 'The changing corporate governance paradigm: implications for developing and transition economies', in S. S. Cohen and G. Boyd (eds.), Corporate Governance and Globalization. Long Range Planning Issues (Edward Elgar, 2000). 
previously contained political economies of nation-states, the more appropriate conceptual approach would be to argue for the need for a transnationalization of corporate governance regulation. In the case of ECGR this would mean to first recognise the need for a differentiated assessment of different nation-state regulatory experiences and their presently continuing variations and innovations. ${ }^{60}$ The next step would then not consist in 'translating' specific regulatory instruments onto the transnational sphere, but, instead, in fostering a radically functionalist understanding of corporate governance. Such an approach would go beyond the now abundant references to 'best practices', which owe their content more to the ideological battles out of which they are emerging than to a truly functionalist governance model. Such a model would have to be developed with the complete corporation, its markets, governance structures, dynamics and contextual performance practices in mind. Building on work regarding 'reflexive law' in the area of corporate governance and corporate environmental responsibilities ${ }^{61}$, a more adequate governance approach would have to start with the corporation itself, complementing simultaneously continuing assessments of the organisational functionalities of the corporation. ${ }^{62}$ While such functionalist approaches to corporate governance are only now emerging ${ }^{63}$, their promise lies in their pursuit of governance models that are evolving directly out of the practice, management and operation of complex business entities on uncertain markets.

${ }^{60}$ For the example of Germany, see only U.Noack/D.Zetzsche, 'Germany's Corporate and Financial Law 2007 (Getting) Ready for Competition', (2007) Center for Business and Corporate Law Research Paper No. 06/2007, available at:

http://ssrn.com/abstract=986357.

${ }^{61}$ G. Teubner, 'Enterprise Corporatism: New Industrial Policy and the 'Essence' of the Legal Person', (1988) 36 Am. J. Comp. L. 130-155; E. Orts, 'Reflexive Environmental Law', (1995) 89 Northwestern University Law Review 1227-1340; K.-H. Ladeur, 'Die Prozeduralisierung des Unternehmens', in D. Hart (eds.), Privatrecht im "Risikostaat" (Nomos, 1997)

${ }^{62}$ R. Kraakman/P. L. Davies/H. Hansmann/G. Hertig/K. J. Hopt/H. Kanda/E. B. Rock, The Anatomy of Corporate Law. A Comparative and Functional Approach (Oxford University Press, 2004)

${ }^{63}$ For the example of a transnational regulatory framework of corporate environmental responsibilities of Multinational Chemical Enterprises, see the excellent study by Martin Herberg, Globalisierung und private Selbstregulierung (2007). 
While this approach would place great emphasis on self-regulation, which would in turn create additional pressure on the regulatory systems with a mandatory-law approach to corporate law ${ }^{64}$, reflexive corporate governance would eventually emerge as a more adequate and flexible approach to corporate law regulation while - at the same time - not necessarily being insulated from ongoing assessments of this hybrid regulatory enterprise. Instead of reacting to the long, tiresome and frustrating harmonisation attempts in European company law with a turn to expert rule and market governance, reflexive corporate governance would allow for a clearer view of how political governance and corporate self-regulation can be mutually reinforcing and optimizing by constantly exposing regulatory choices and practices to scrutiny. The prime advantage of this approach would be that the regulatory challenges facing today's transnational corporations could be assessed in correlation with the ongoing transformation of the political economies in which companies are legally constituted. ${ }^{65}$ A reflexive approach to corporate governance is even more pressing as the dramatically unfolding debate over a present transition from a 'real economy' to a 'financial economy ${ }^{\text {'66 }}$ suggests that neither a return to embedded capitalism corporate governance regulation nor a undeterred belief in the 'end of history of corporate law ${ }^{\text {,67 }}$ with its dubious promises of triumphant shareholder value maximization are a viable option. This means that what would previously have been an

${ }^{64}$ See K. J. Hopt, 'Common Principles of Corporate Governance in Europe?' in J. A. McCahery,P. Moerland,T. Raaijmakers and L. Renneborg (eds.), Corporate Governance Regimes. Convergence and Diversity (Oxford University Press, 2002).

${ }^{65}$ For the observation that even the ECJ's decisions in Centros and others since 1999, which facilitated greater corporate mobility, have neither significantly induced more foreign incorporation nor more regulatory competition, see W.Bratton/J.McCahery/E.Vermeulen, 'How does Corporate Mobility Affect Lawmaking? A Comparative Analysis, (2008), ECGI Law Working Paper No. 91/2008, available at: http://ssrn.com/abstract $=1086667$

${ }^{66}$ Frank Partnoy, 'Financial Innovation and Corporate Law', (2007), University of San Diego Legal Studies Research Paper No. 07-89, available at: http://ssrn.com/abstract=976931

${ }^{67}$ H. Hansmann/R. Kraakman, 'The End of History for Corporate Law', (2001) 89 Geo. L. J. 439-468; H. Hansmann, 'How Close is the End of History?' (2006) 31 J. Corp. L. 745750 
interest-pluralist assessment of choices in corporate governance regulation with view to allegedly opposed and eventually irreconcilable stakeholder interests can now be transposed into a more comprehensive and contextual analysis of the corporation's functions, in particular, of its embeddedness in operational and regulatory practices.

Against this background, it is important to contextualize ECGR again within the otherwise unfolding dynamics of hybrid governance modes within the EU. Echoing earlier legitimacy concerns with the OMC, recent explorations of 'new', 'experimentalist' or 'informal'68 governance critically address the instrumentalisation of decentralised self-governance in service of a larger 'whole', the problem being that both the accessibility of the implied, overall political goal along with the now available regulatory modes are becoming ever more precarious. ${ }^{69}$ As Charles Sabel and Jonathan Zeitlin have recently argued, the persistent legitimacy critique vis à vis soft and hybrid governance forms 'crucially overlooks the underlying architecture of public rule making in the EU: the fundamental design for law making, and the way this design transforms the distinct elements of EU governance by connecting them into a novel whole. ${ }^{70}$ The particular challenge arising from these forms of governance is, however, the growing pressure on actors participating in multi-level norm-creation processes to effectively identify the desired output and the coordination elements necessary for its realization. 'The difficulty [...] and the open secret of administrative law in both the EU and the USA, is that it is very often - regularly? - the case that no actor among those seeking to coordinate their efforts has a precise enough idea of the goal either to give precise instructions to the others or reliably recognise when their actions do or don't serve the specified end. ${ }^{71}$ In defense of what they call 'experimentalist governance', Sabel and Zeitlin extrapolate the legitimacy potentials of the 'recursive redefinition of means and ends' at

${ }^{68}$ B. Eberlein/E. Grande, 'Beyond Delegation: Transnational Regulatory Regimes and the EU Regulatory State', (2005) 12 J. Eur. Publ. Pol. 89

${ }^{69}$ G.Majone, Dilemmas of European Integration: The Ambiguities \& Pitfalls of Integration by Stealth (Oxford University Press, 2005)

${ }^{70}$ C. F. Sabel/J. Zeitlin, 'Learning from Difference: The New Architecture of Experimentalist Governance in the EU', (2008) 14 European L.J. 271-327, at 273

${ }^{71}$ Id., at 304 
its heart by pointing out that under conditions of complex regulatory challenges an accountability model designed for a hierarchical principalagent relation is no longer adequate. ${ }^{72}$ Instead of assessing whether the agent did comply with a rule set by the principle, the agent is expected to provide 'a good explanation for choosing, in the light of fresh knowledge, one way of advancing a common, albeit somewhat indeterminate project (as all projects are).' [...] Correspondingly, '[p]eer review becomes in turn dynamic accountability - accountability that anticipates the transformation of rules in use - and dynamic accountability becomes the key to "anomalous" administrative law [...]. ${ }^{73}$ The authors certainly recognise the limitations of the proposed endorsement of experimental governance, when they address the tension between the described participatory processes and democracy. But, their response is radical: while acknowledging the unavailability of a large scale democratic justification of the new system of governance, Sabel and Zeitlin emphasise how accountability-through-peer review can help destabilise "entrenched forms of authority - starting with, but not limited to technical authority. ${ }^{, 74}$ Importantly, they argue, the "diffusion of procedural commitments to transparency and participation in EU networked governance has had a democratising destabilisation effect in terms of stimulating demands to widen the circle of actors and alternatives involved in policy making at the national as well as the European level. ${ }^{75}$

This short discussion of EU 'experimentalist' governance modes points to the deeper complexity of tying an exploration of ECGR into the context of European governance. As the following case study will illustrate, the particular challenge arises from the intersection of national and transnational law making in an overall hotly contested regulatory area. There has been and continues to be considerable pressure on European corporations to become more attractive to foreign investors, first, by both changing core corporate governance rules and, second, by substantively expanding its disclosure portfolio. The peculiar trajectory of the European

\footnotetext{
${ }^{72} I d$.

${ }^{73} I d$., at 305

${ }^{74} I d$., at 313

${ }^{75} \mathrm{Id}$., at 315-316
} 
attempt at introducing standards regarding the disclosure of executive compensation can be used to highlight the persistent tension between 'old' and 'new' EU governance.

\section{THE CASE OF EXECUTIVE COMPENSATION}

\section{A. BREAKING THE DEADLOCK: GOVERNANCE BY EXPERTISE}

While it has oft been repeated that there is no universally optimal system of corporate governance and that, despite upheld claims of an 'end of history in corporate law', there is much likelihood for continued divergences and persistence of distinct regimes, the case of management compensation illustrates the changing dynamics within the ECGR process. As hard law harmonization in the area of company law seems to be out of reach $^{76}$, soft law harmonization might prove to be a far more efficient approach to regulatory change in that respect. While company law experts in the 1970s harbored highest hopes for a flourishing harmonization program of company laws in Europe ${ }^{77}$, the ensuing decades have received a much more reserved assessment. Over time it became apparent that harmonization could not be achieved in many central areas of company law given the substantial, political, socio-economic and legal differences of company law organization in the European member states. ${ }^{78}$ Instead, the European Commission as the principle initiator of European wide company law legislation pursued various projects in the area of capital

\footnotetext{
76 J. Wouters, 'European Company Law: Quo Vadis?' (2000) 37 Common Market Law Review 257-307; S. Deakin, 'Regulatory Competition versus Reflexive Harmonisation in European Company Law', in D. C. Esty and D. Geradin (eds.), Regulatory Competition and Economic Integration. Comparative Perspectives (Oxford University Press, 2001); P. Zumbansen, 'Spaces and Places: A Systems Theory Approach to Regulatory Competition in European Company Law', (2006) 12 Eur. L. J. 534-556

77 See above all C. Schmitthoff, 'The Future of the European Company Law Scene', in C. Schmitthoff (eds.), The Harmonisation of European Company Law (The U.K. Nat'l. Committee of Comparative Law, 1973).

${ }^{78}$ See K. J. Hopt, 'Common Principles of Corporate Governance in Europe?' in J. A. McCahery,P. Moerland,T. Raaijmakers and L. Renneborg (eds.), Corporate Governance Regimes. Convergence and Diversity (Oxford University Press, 2002).
} 
market and securities law, which would remain, until very recently, the only areas where Brussels could function as a law making motor. ${ }^{79}$ Recently, much of this well-known status quo has come into greater movement. Among the events and developments that have contributed to a notable increase in legislative activity in this area are the already mentioned Societas Europaea and the Takeover Directive, the ECJ's judgment in Centros and follow-up decisions in 2002, 2003 and 2004, and a fourth and in many ways very promising development, which had been initiated by the Commission amidst of the turmoil surrounding the deliberations around the Takeover Directive. In 2002, the Commission mandated the so-called High Level Group of Company Law Experts under the chairmanship of Dutch law professor, Jaap Winter, to prepare a comprehensive report to facilitate the Directive's adoption. ${ }^{80}$ Shortly after the Group had submitted its report, the Commission asked for another study. This mandate constituted the starting point for an entirely new wave of European company law making. When the Winter-Group submitted its Report of the High Level Group of Company Law Experts on A Modern Regulatory Framework for Company Law in Europe in November 2002 (the "Winter 2" report), it did no less than present an outline, blueprint and wish-list for future legislative projects for the European company law legislator. ${ }^{81}$ Based on the Winter 2 report, the Commission drafted a concise outline of future legislative projects, the 'Modernising Company Law and Enhancing Corporate Governance in the European Union - A Plan to Move Forward', the so-called Action Plan. ${ }^{82}$ Given the wide range

${ }^{79}$ For an overview of these initiatives, see the excellent account by J. Wouters, 'European Company Law: Quo Vadis?' (2000) 37 Common Market Law Review 257-307; see also C. Villiers, European Company Law: Towards Democracy? (Ashgate, 1998); V. Edwards, EC Company Law (Oxford University Press, 1999)

80 See the report J. Winter, 'Report of the High Level Group of Company Law Experts on Issues related to Takeover Bids', (2002) at http://europa.eu.int/comm/internal_market/company/docs/takeoverbids/2002-01-hlgreport_en.pdf

81 J. Winter, 'Report of the High Level Group of Company Law Experts on A Modern Regulatory Framework for Company Law in Europe', (2002) at http://ec.europa.eu/internal_market/company/docs/modern/report_en.pdf

82 Document COM(2003)284, available at: $\underline{\text { http://eur- }}$ lex.europa.eu/LexUriServ/site/en/com/2003/com2003 0284en01.pdf (last visited 5 June 2008) 
of issues addressed in its Action Plan, including, inter alia, corporate governance disclosure, strengthening of shareholder rights, modernizing corporate boards and co-ordinating the corporate governance efforts of member states ${ }^{83}$, the Commission invited public comments designed to assist it in the realization and implementation of the Action Plan's agenda. ${ }^{84}$ When, in November 2003, the Directorate General Internal Market, the Commission's subdivision responsible for company law, issued a synthesis of the responses received on the Action Plan ${ }^{85}$, it highlighted the overwhelming public support for the attempt embodied in the Action Plan to work towards a higher capital market efficiency and enhanced confidence in the market. ${ }^{86}$ It further reiterated that many participants in the consultation had stressed the necessity of a "fully integrated approach combining self-regulatory market solutions, adequate co-ordination of corporate governance codes and legislation where necessary" while recognizing that there cannot be a one-size-fits-all solution $^{87}$ for corporate governance in Europe. In light of the continuing differing company law structures in Europe and the differences in the political economies among member states, it has been the consensus for some years now to not pursue a uniform corporate governance model but to enhance better transparency, communication and learning across member state borders. ${ }^{88}$

${ }^{83}$ ACTION PLAN, supra, 10-17

${ }^{84}$ ACTION PLAN, supra, at 22

${ }^{85}$ http://ec.europa.eu/internal_market/company/docs/modern/governance-consultresponses_en.pdf (last visited 5 June 2008)

${ }^{86}$ SYNTHESIS, supra, preceding note, at 5.

${ }^{87} I d$., at 6 .

${ }^{88}$ According to EU Internal Market Commissioner, Charlie McCreevy, in a speech at the Corporate Governance Forum on 20 January 2005, there is neither need nor political will for a European wide corporate governance code: "We see no need for this at present and the adoption of such a code, if it were even possible, would be an inevitable and possibly messy political compromise, which would be unlikely to achieve full information for investors about the key corporate governance rules.” Available at: http://europa.eu/rapid/pressReleasesAction.do?reference=SPEECH/05/26\&format=HTM L\&aged=1\&language $=$ EN\&guiLanguage $=$ en (last visited 5 June 2008); see also ACTION PLAN, supra, at 11: “... no need for an EU corporate governance code.” 


\section{B. GOVERNANCE BY TRANSPARENCY}

Among the more recently pursued issues, however, by the lawmakers in Brussels, was a European wide regime for executive compensation. Already highlighted in the Winter 2 report $^{89}$, the Action Plan of May 2003 reemphasized the need for an initiative in this regard, which would basically be oriented around the central principles of shareholder approval and full, i.e. individualized, disclosure of the compensation schemes. ${ }^{90}$ The Commission acted in this regard by issuing, on 14 December 2004, a Recommendation" ${ }^{91}$ : "fostering an appropriate regime for the remuneration of directors of listed companies."92 Under (3), the Commission highlighted the central role of the compensation scheme's disclosure for good corporate governance: "The disclosure of accurate and timely information by the issuers of securities builds sustained investor confidence and constitutes an important tool for promoting sound corporate governance throughout the Community."93 One of the remarkable features of this Recommendation was that it addressed questions of disclosure over any substantive issues related to directors' remuneration. While the Recommendation subsequently addressed 'remuneration policy', 'remuneration of individual directors', 'share-based remuneration', and 'information', its central focus was on issues of transparency, disclosure and effective communication of the compensation details to shareholders and investors. The Commission addressed this Recommendation to the Member States ${ }^{94}$ and underlined the necessity of Member States taking

\footnotetext{
${ }^{89}$ J. Winter, 'Report of the High Level Group of Company Law Experts on A Modern Regulatory Framework for Company Law in Europe', (2002) at http://ec.europa.eu/internal_market/company/docs/modern/report_en.pdf, 9, 64-67

90 Action Plan, supra, at 16.

${ }^{91}$ A recommendation is a non-binding act by the Commission, pursuant to Art. 211 EC second indent, to "deliver opinions on matters dealt with this in this Treaty, if it expressly provides so or if the Commission considers it necessary."

92 2004/913/EC, of 14 December 2004, available at: http://eurlex.europa.eu/LexUriServ/site/en/oj/2004/1_385/1_38520041229en00550059.pdf (last visited 5 June 2008)

${ }^{93}$ Id.

${ }^{94} \mathrm{Id}$., at 8.2.
} 
"all appropriate measures" to ensure that companies registered in their jurisdictions have regard to this Recommendation. ${ }^{95}$

To understand the particular dynamics of European law making, mention should be made of the discernible tension between Brussels' political will to install a European wide regime on the one hand and its awareness of the numerous obstacles on the other: The Recommendation did in very explicit terms highlight the political embeddedness of the remuneration regime within the greater system of corporate governance. (2) of the Recommendation reads:

'...remuneration is one of the key areas where executive directors may have a conflict of interest and where due account should be taken of the interests of shareholders. Remuneration systems should therefore be subjected to appropriate governance controls, based on adequate information rights. In this respect, it is important to respect fully the diversity of corporate governance systems within the Community, which reflect different Member States' views about the roles of corporations and of bodies responsible for the determination of policy on the remuneration of directors, and the remuneration of individual actors. ${ }^{96}$

This section expresses - in very simple terms - one of the most compelling features of European company law development, i.e. the great divergence between different company law traditions and histories. ${ }^{97}$ While the history of ECGR has long been marked by struggles over

${ }^{95}$ Id., Section 1, 1.1.

96 European Commission, Recommendation 2004/913/EC, of 14 December 2004, (2) L $385 / 55$, at 55 .

97 See, for example, the brief accounts in Mark Roe, Political Determinants of Corporate Governance (Oxford University Press, 2003); see, from a political economy perspective, Ronald Dore, Stock Market Capitalism: Welfare Capitalism (Oxford University Press, 2000). 
nationally distinct corporate governance regimes ${ }^{98}$, more recent accounts document the origins, causes and prospects for change. ${ }^{99}$ As already alluded to, the regulatory changes taking place in Brussels and in various Member States strongly reflect trends of parallel law making initiatives that on the one hand involve official norm-setting bodies such as the Commission and the Member States' parliaments, and on the other, nonstate actors, expert commissions and private enterprises, complementing or accompanying the official law making processes through an amalgam of private, informal law making regimes. ${ }^{100}$ The particular challenge lies in the proliferation of sites, levels and forms of law making. As is shown next through a brief account of the German response to the European Recommendation, norms are sometimes the result of a highly intricate and unpredictable political process, during which the legislative initiative moves back and forth between domestic and supranational (Berlin Brussels) and between in-official and official lawmakers (Expert Commission - Federal Legislator).

The Commission's Recommendation of December 2004 soon began to trigger reactions in Member States that - according to para. 8.1. of the Recommendation - were 'invited to take the necessary measures to promote the application [...] by 30 June 2006.' According to the legal, non-binding nature of this regulatory instrument, Member States were invited 'to notify the Commission of measures taken in accordance with the Recommendation in order to allow the Commission to monitor closely the situation and, on this basis, to assess the need for further measures.' Not only did the Recommendation appear to be just about one of the most

98 See the classical account by C. Schmitthoff, 'The Future of the European Company Law Scene', in C. Schmitthoff (eds.), The Harmonisation of European Company Law (The U.K. Nat'l. Committee of Comparative Law, 1973); for a more recent observation and overview, see Hopt, 'Common Principles of Corporate Governance in Europe?', in: Corporate Governance Regimes: Convergence and Diversity (McCahery et al. eds. 2002), 175.

99 G.Hertig, 'Western Europe’s Corporate Governance Dilemma’, in: (1996) Liber Amicorum Richard Buxbaum, at 265; P.Zumbansen, 'European Corporate Law and National Divergences: The Case of Takeover Regulation’, in: (2004) 3 Wash U Glob St L Rev 867 (2004).

100 See Baums, Interview: Reforming German Corporate Governance, 2 German L.J. No. 12 (16 July 2001), available at: http://www.germanlawjournal.com/article.php?id=43 
elegant, non-coercive and perhaps most permeating legal instruments in a highly politically contested regulatory environment, but it also might have offered just the right amount of pressure and substance to allow Member States to domestically pursue certain policies that otherwise might have proven too politically sensitive.

At the core of this small case-study is the 'law' governing the disclosure of executive compensation in large, publicly traded business corporations. In recent years, there has been much development in this area, mostly initiated by public resistance against high pay packages for corporate leaders all too often now associated with excessive rent-seeking and fraudulent behaviour. ${ }^{101}$ Academic work alone on the issue of executive compensation - while having grown with the rise in real-world compensation during the 1990s bull market - has eventually outgrown this development. ${ }^{102}$ Even a superficial survey of the media and the scholarly literature suggests that the topic has not ceased to attract immense attention - from the academy and policy advisory circles to the media and the general public. The mood regarding the subject, however, might have - or so we hope - matured over time. With allegedly or potentially everyone driving a BMW in parts of California a few years ago, the perception of success in the market was that it was generally accompanied and documented by steep increases in management pay. With Bernard Ebbers convicted by a jury that remained utterly unimpressed by his pleas

${ }^{101}$ See e.g. Fat Cats Feeding - Executive Pay, ThE ECONOMIST, Oct. 11, 2003, U.S. Edition, available at http://www.econ.umn.edu/ edgar/Economist.pdf (observing a 60\% increase of media mentionings of "fat cats" between 2002 and 2003, making executive pay corporate governance’s greatest worry); CEO pay: Fat Cats turn to low fat, The Economist, March 5, 2005, print edition, p. 14 (warning against a continuation of "lavish” payments to CEO - including ousted ones); see also Sandeep Gopalan, Say on Pay, and the SEC Disclosure Rules: Expressive Law and CEO Compensation', (2008) Pepperdine L. R. forthcoming, available at http://ssrn.com/abstract=1096647 (last visited 2 April 2008), 1: "Excessive CEO compensation is the cause celebre of current corporate law."

102 Bebchuk, Fried and Walker, Management and Control of the Modern Business Corporation: Executive Compensation and Takeovers, 69 U Chi L R 751, 753 (2002); L. A. Bebchuk/J. Fried, Pay Without Performance. The Unfulfilled Promise of Executive Compensation (Harvard University Press, 2004) 
of ignorance vis-à-vis the fraudulent events in Enron ${ }^{103}$, today's discussion about executive compensation seems again to be moving in another direction. Generally, the attitudes rank from skepticism to outright hostility with regard to the increasingly mediatized compensation programs. ${ }^{104}$ In the shadow of the dramatic and existential destruction of real capital and lifelong earnings with the collapse of the dot.com market in $2002^{105}$, it may come as little surprise that the discussion about management pay has again risen to the fore of public attention. ${ }^{106}$

Academic debate has played a large role in giving voice to the various positions defended in this regard. ${ }^{107}$ William Bratton, in an insightful

${ }^{103}$ Carrie Johnson, Ebbers Gets 25-Year Sentence For Role in WorldCom Fraud, WASHINGTON POST, 14 July 2005, at: http://www.washingtonpost.com/wpdyn/content/article/2005/07/13/AR2005071300516.html; see also Johnson, Enron's Lay Dies Of Heart Attack. Convicted Founder Faced Life in Prison, Washington Post, 6 July 2006, at: http://www.washingtonpost.com/wpdyn/content/article/2006/07/05/AR2006070500523.html (reporting on heart attack of convicted former Enron chairman) (last visited 5 June 2008)

104 See Knowledge @ Wharton: SEC's Spotlight on Executive Pay. Will it make a Difference?, 8 February 2006; see also Executive Excess Report: CEO Pay Soars at Companies That Send Jobs Abroad, 22 September 2004, at: http://www.leftcenterleft.com/2004-09-22-outsoucing-and-ceo-pay.html (last visited 5 June 2008)

${ }^{105}$ For a concise account of Enron's downfall, see W. W. Bratton, 'Enron and the Dark Side of Shareholder Value', (2002) 76 Tul. L. Rev. 1275-1361; see also S. Deakin/S. J. Konzelmann, 'Learning from Enron', (2004) 12 Corporate Governance 134-142.

106 Besides numerous instances of post-Enron press coverage, see from the academic debate Bebchuk et al., supra note 5; R. S. Thomas, 'Explaining the International CEO Pay Gap: Board Capture or Market Driven?' (2004) 57 Vanderbilt Law Review 1171-1267; F. G. Snyder, 'More Pieces of the CEO Compensation Puzzle', (2003) 28 Delaware Journal of Corporate Law 129-183; M. C. Jensen/K. J. Murphy/E. G. Wruck, 'Remuneration: Where we've been, how we got here, what are the problems, and how to fix them', (2004) ECGI Working Paper Series in Law, WP No. 44/2004 .

107 See only the grand attack by L. A. Bebchuk/J. Fried, Pay Without Performance. The Unfulfilled Promise of Executive Compensation (Harvard University Press, 2004), and the response by W. W. Bratton, 'The Academic Tournament over Executive Compensation', (2005) 93 Cal. L. Rev. 1557-1584, at 1557: "Executive pay brings out the worst in the corporate-governance system. No economic theory tells us the terms of an "optimal" pay arrangement that penalizes failure while rewarding effort and merit in just the right increments. Absent such a first-best template, we must rely on contracting 
discussion and critique of Bebchuk and Fried's important book ${ }^{108}$, recognizes in this discussion not merely an opposition between anti- and pro-management arguments, but a "contest for shareholder capitalism's high ground."109 This observation is particularly poignant as it highlights that within the quarrel, notably not so much over the amount of compensation paid, but over whether this amount is adequately tied to the management's success in creating shareholder value, there ought still be some room to question the starting premise, namely whether one can continue to reasonably define the firm's objective by no more and no less than shareholder value maximization. ${ }^{110}$

A recurring argument at present deliberations over excessive CEO pay and the promises of controlling management behaviour through the addition of stock-driven components into their salary, is the contention that the issue of incentivizing management behaviour is really more complicated than that. Closely tied to this contention is the suggestion that the corporation is really more complicated than SHV theory might sometimes be taken to suggest. ${ }^{111}$ As a result, the connection made between CEO compensation

practice and experience to teach us on a trial-and-error basis.” This debate was mostly spurred by work done by Michael Jensen and Kevin Murphy: see M. C. Jensen/K. J. Murphy, 'Performance Pay and Top-Management Incentives', (1990) 98 J. Pol. Econ. 225-264; on this debate and in reaction to Bebchuk and Fried, see recently Arthur Levitt, Corporate Culture and the Problem of Executive Compensation, 30 J. CORP. L. 749 (2005); Bevis Longstreth, A Real World Critique of Pay Without Performance, $30 \mathrm{~J}$. CORP. L. 767 (2005); S. M. Bainbridge, 'Executive Compensation: Who Decides?' (2005) 83 Tex. L. Rev. 1615-1662; J. McConvill, 'Executive Compensation and Corporate Governance: Rising above the "Pay-for-Performance" Principle', (2006) 43 Am. Bus. L.J. 413-438; J. McConvill, 'Positive Corporate Governance and its Implications for Executive Compensation', (2005) 6 German Law Journal 1777-1804.

108 L. A. Bebchuk/J. Fried, Pay Without Performance. The Unfulfilled Promise of Executive Compensation (Harvard University Press, 2004)

109 W. W. Bratton, 'The Academic Tournament over Executive Compensation', (2005) 93 Cal. L. Rev. 1557-1584, at 1559

110 Id., Bratton notes how, since the 1990s, a shift had taken place towards equity based CEO compensation, see id., at 1558, with references to M. C. Jensen/K. J. Murphy, 'Performance Pay and Top-Management Incentives', (1990) 98 J. Pol. Econ. 225-264.

${ }^{111}$ W. Lazonick/M. O'Sullivan, 'Maximizing Shareholder Value: A New Ideology for Corporate Governance', in W. Lazonick and M. O'Sullivan (eds.), Corporate Governance and Sustainable Prosperity (Palgrave Macmillan, 2002) 
packages and these CEOs' success in creating shareholder value underscores the theoretical paradigm which sees the corporation, in rough terms, less as an entity channelling and collectivizing various interests, ranging from investors over employees and creditors to society at large, but as a nexus of contractual relations, entered into solely with the creation of shareholder profit in mind. ${ }^{112}$ In their description of how the model of the firm, emerging from the substitution of smaller, closely held and founder-governed enterprises by large, publicly traded corporations between 1880 and $1930^{113}$, placed the investors at the mercy of their managers, Adolf Berle and Gardiner Means ${ }^{114}$ pointed out that the real challenge of reconciling the separation of ownership and control lay in a realistic and context-sensitive appreciation of the evolving political economy of corporate practice and corporate regulation. Here lies the key to undoing much of the more recent apprehension of Berle \& Means as forerunners of the Shareholder Value paradigm. ${ }^{115}$ The disembedding of Berle \& Means' work occurred at a time of increasingly vibrant securities markets in the 1980s by reducing their argument to a mere call to arms in favour stronger management control in the interest shareholders. This move paid - and continues to pay - little to no attention to the contemporary political economy, management and ownership structure at

112 See M. C. Jensen, 'Value Maximization, Stakeholder Theory, and the Corporate Objective Function', (2001) 14 Journal of Applied Corporate Finance; see already M. C. Jensen/W. H. Meckling, 'Theory of the Firm: Managerial Behavior, Agency Costs, and Ownership Structure (1976)', (2000) in: Jensen, A Theory of the Firm, Governance, Residual Claims, and Organizational Forms orig. in: 3 Journal of Financial Economics 305-360 (1976), 83-135; A. A. Alchian/H. Demsetz, 'Production, Information Costs, and Economic Organization', (1972) 62 American Economic Review 777-795.

113 B. R. Cheffins, 'Corporations', in P. Cane and M. Tushnet (eds.), The Oxford Handbook of Legal Studies (Oxford University Press, 2003), 487

114 A. A. Berle/G. C. Means, The Modern Corporation and Private Property 1932)

${ }^{115}$ For Berle's early arguments supporting shareholder primacy, see: Adolf A. Berle, Jr., Non-cumulative Preferred Stocks, 23 Colum. L. Rev. 358 (1923); Adolf A. Berle, Jr., Problems of Non-Par Stocks, 25 Colum. L. Rev. 43 (1925); Adolf A. Berle, Jr., Participating Preferred Stock, 26 Colum. L. Rev. 303 (1926); Adolf A. Berle, Jr., NonVoting Stock and Bankers Control, 39 Harv. L. Rev. 673 (1926); Adolf A. Berle, Jr., Corporate Powers as Power in Trust, 44 Harv. L. Rev. 1049 (1931); and Adolf A. Berle, Jr., For Whom Corporate Managers are Trustees: A Note, 45 Harv. L. Rev. 1365 (1932). 
the time of Berle \& Means' writing. ${ }^{116}$ Berle \& Means did not contend themselves with critiquing the challenge of the threatening 'separation of ownership and control'. Instead, they made clear, and Berle would go to emphasize this point much more strongly some decades later ${ }^{117}$, that the corporation also ought to be understood as an eminently important social and political institution. ${ }^{118}$ While Berle and Means's critique of an unaccountable management caste continued to dominate corporate law thinking for decades to come, since the 1960s, economists and corporate law authors asked why, if the separation of ownership and control thesis was correct, investors had not been deterred from buying corporate shares. Their response, which would prove to remain influential to our present day, was in short that besides internal governance and control mechanisms such as shareholder suits or the firing of executives, there were also alternative, outside control mechanisms. As advanced by Henry Manne ${ }^{119}$, but also by others writing on regulatory competition ${ }^{120}$, the market for corporate control would exercise a strong enough control mechanism to keep management within range. ${ }^{121}$ The management's concern with how the market assesses the value of the firm under their guidance allegedly made it responsive to market opinion, most powerfully addressed by the selling of shares, reduction in value and acquisition/take-over by another corporation, which would regularly replace the incumbent management.

\footnotetext{
${ }^{116}$ For a comprehensive assessment of the origins and trajectories of Berle \& Means' work, see Fenner Kennedy-Stewart, , A Critical History of The Early American Shareholder Primacy Discourse: A Fresh Examination of the Writings of Adolf A. Berle, E. Merrick Dodd and Henry G. Mann, Ph.D. Thesis Osgoode Hall Law School, draft ms., on file with author); see also Bratton, Tsuk Mitchell

117 A. A. Berle, The 20th Century Capitalist Revolution (Harcourt, Brace \& World, 1954) (highlighting the political power held and used by large corporations in the contemporary political economy).

118 B. R. Cheffins, 'Corporations', in P. Cane and M. Tushnet (eds.), The Oxford Handbook of Legal Studies (Oxford University Press, 2003), at 487

119 H. Manne, 'Mergers and the Market for Corporate Control', (1965) 73 Journal of Political Economy 110-120

120 See, fundamentally, C. M. Tiebout, 'A Pure Theory of Local Expenditures', (1956) 64 Journal of Political Economy 416-424.

121 See hereto W. J. Carney, 'The Political Economy of Competition for Corporate Charters', (1997) 26 J. Leg. Stud. 303-329.
} 
This emerging understanding of the separation of ownership and controlproblem prepared the ground for the rise of the nexus-of-contracts model of the corporation, which spread, aided by the rise of the law \& economics movement, like a prairie fire through the 1970 s corporate law arena. ${ }^{122}$ The nexus-model shifted the focus significantly, but much of this shift had already been announcing itself with a growing disillusionment with government regulation all throughout the 1980 s and $1990 \mathrm{~s}^{123}$, culminating eventually in the rise to power by Margaret Thatcher in the United Kingdom and Ronald Reagan in the United States. The contractarian model, thus, fit smoothly into a larger political climate where emphasis was placed on individual responsibility, private ordering and the greater burden on the state to justify any intervention. To be sure, a considerable amount of critique was and continues to be mounted against the contractarian premises of corporate governance. ${ }^{124}$ What matters for our discussion, however, is not the final resolution of the debate over the nexus-model of the corporation, but the recognition of this model as an important theoretical background for any concept of non-state regulation of the corporation. This section on the development of corporate law theory already indicates that there can be no adequate understanding of the regulatory framework for the corporation without an exposure to the various lines of contestation of the firm itself. ${ }^{125}$ In fact, what makes the discussion of executive compensation so interesting, and Bratton's observation even more insightful, is that we can recognize a set of much more fundamental questions that underlie the different contentions about competences to determine compensation packages. These questions concern our understanding and concept of the corporation as a regulatory object, subject and space.

${ }^{122}$ D. M. Branson, 'A Corporate Paleontologist's Look at Law and Economics in the Seventh Circuit', (1989) 65 Chicago Kent Law Review 745-756, 745

${ }^{123}$ B. R. Cheffins, 'Corporations', in P. Cane and M. Tushnet (eds.), The Oxford Handbook of Legal Studies (Oxford University Press, 2003), 494

124 See, e.g., W. W. Bratton/J. A. McCahery, 'Incomplete Contracts Theories of the Firm and Comparative Corporate Governance', (2001) 2 Theoretical Inquiries in Law Article 7 [p. 1-38]

125 See, hereto, P. Ireland, 'Shareholder Primacy and the Distribution of Wealth', (2005) 68 Modern Law Review 49-81. 
One particular element of the current discussion and our reason to draw from the example of executive compensation for our argument is the particular dynamics of regulatory politics in this area. As already indicated, we can note an interesting shift away from the material issues of how much CEOs are being paid, who sets the compensation packages and how justified these payments are ${ }^{126}$, to questions regarding the regulatory framework of executive compensation. While the extreme amounts being distributed to top management surely remain on academics, ${ }^{127}$, policy makers' and the public's mind, an intriguing discussion has emerged which addresses this problem from another perspective. It is this perspective on the regulatory structure of executive compensation, the related competences ${ }^{128}$ and now, more importantly, its disclosure that ought to be moved into the centre of attention. ${ }^{129}$ While the regulation and disclosure of CEO pay figures as a means of controlling management, be that on a running, day-to-day basis or in the context of corporate acquisitions ${ }^{130}$, remains an interesting aspect of the present discussion, an even more fruitful approach to understanding the regulatory dynamics of executive compensation would be to focus on how the various forms of corporate disclosure can be read as new means of regulating the company as such. ${ }^{131}$

${ }^{126}$ See, e.g., Susan J. Stabile, One for A, Two for B, and Four Hundred for C: The Widening Gap in Pay Between Executives and Rank and File Employees, 36 MicH. J.L. REFORM 115, 115-18 (2002).

127 W. W. Bratton, 'The Academic Tournament over Executive Compensation', (2005) 93 Cal. L. Rev. 1557-1584, 1561: "CEO compensation has ballooned (9-10), with total remuneration increasing by more than eleven times in the past thirty years."

${ }^{128}$ See S. M. Bainbridge, 'Executive Compensation: Who Decides?' (2005) 83 Tex. L. Rev. 1615-1662.

${ }^{129}$ L. A. Bebchuk/J. Fried, Pay Without Performance. The Unfulfilled Promise of Executive Compensation (Harvard University Press, 2004), 212-3; S. M. Bainbridge, 'Executive Compensation: Who Decides?' (2005) 83 Tex. L. Rev. 1615-1662, 1655 (noting the impediments in particular for small shareholders to make effective use of the wealth of disclosed information, leaving mostly professional, institutional investors to make informed choices on the basis of corporate disclosure)

130 Bainbridge, id.

${ }^{131}$ For a comparative overview, see L. Enriques/P. Volpin, 'Corporate Governance Reforms in Continental Europe', (2007) 21 J. Econ. Persp. 117-140, 132-5. 
The latter feeds into a parallel, contemporary debate about mandatory vs. voluntary disclosure, a discussion, which emerged in the aftermath of government regulation after the financial scandals of firms such as ENRON, WorldCom and Tyco. Here we find ourselves again in the midst of longstanding and dramatically urgent deliberations over state vs. market based approaches to securities regulation. ${ }^{132}$ Central to this discussion over the merits or drawbacks of voluntary vs. mandatory disclosure is the fundamental recognition of disclosure and transparency as regulatory means. As recently reiterated by Cynthia Williams, the recognition of disclosure as a regulatory instrument, certainly, goes back a long time, at least to the work done by Brandeis, Berle and Means. ${ }^{133}$ The present discussion focuses predominantly on the positive effects (or, the lack thereof) of the U.S. government's regulatory initiatives after ENRON,

132 R. Romano, 'Empowering Investors: A Market Approach to Securities Regulation', (1998) 107 Yale L. J. 2359-2430; R. Romano, 'Less is More: Making Institutional Investor Activism a Valuable Mechanism of Corporate Governance', in J. A. McCahery,P. Moerland,T. Raaijmakers and L. Renneborg (eds.), Corporate Governance Regimes. Convergence and Diversity (Oxford University Press, 2002); S. Choi, 'Regulating Investors Not Issuers: A Market-Based Proposal', (2000) 88 Cal. L. Rev. 279334; see, hereto, R. A. Prentice, 'The Inevitability of a Strong SEC', (2006) Cornell L. Rev. 775-839, at 781: “A company can benefit when it develops a reputation for disclosing accurate information to investors. In theory, then, we should not need an SEC to enforce voluntary, accurate disclosure. Corporate practices of the last decade or so, however, stand in marked contrast to economic theory.” Prentice, therefore, argues against models of voluntary disclosure and even regulatory competition. See, id., at 816: "In the end, voluntary full disclosure seldom occurs in the real world."

133 C. A. Williams, 'The Securities and Exchange Commission and Corporate Social Transparency', (1999) 112 Harv. L. Rev. 1197-1311, 1211 with references to L. D. Brandeis, Other People's Money and How the Bankers Use It (Harper's Torch Books, 1914), and to A. A. Berle/G. C. Means, The Modern Corporation and Private Property 1932). But, see also J. W. Landis, The Administrative Process (Yale University Press, 1938) (highlighting the necessity of a strong SEC to regulate corporate disclosure practices). 
most notably the Sarbanes-Oxley Act of $2002^{134}$, which has subsequently come under heavy fire. ${ }^{135}$

What is to be taken from this discussion for our present inquiry into the conditions of ECGR as transnational legal pluralism is the focus on the idea of regulation through disclosure, which constitutes an alternative to substantial regulatory approaches. The example of disclosure of corporate earnings allows us to explore the intertwining of substantive standards and formal procedures, as it plays out in this area in a most intriguing way. Whereas the substantial issue at hand would primarily be what would be considered an adequate compensation scheme, the secondary issue would be who - investors, directors, managers - should be authorized to establish the amount of compensation to be allocated to a company's top management. ${ }^{136}$ The first issue would be the substantive question regarding the adequacy of the compensation package, while the second issue would go to the heart of the corporate governance problem, namely,

134 Public Company Accounting Reform and Investor Protection (Sarbanes-Oxley) Act, Pub. L. No. 107-204, 116 Stat. 745 (2002) (codified as amended in scattered sections of 15, 18 U.S.C.

135 Jenny Strasburg, 'Corporate Backlash over Sarbanes-Oxley’, San Francisco Chronicle, March 23, 2005, available at: http://www.sfgate.com/cgibin/article.cgi?f=/c/a/2005/03/23/BUGVCBR78D43.DTL; Tracey L. Coenen, 'Reflections on Sarbanes-Oxley Act of 2002', Wisconsin L. J., published 13 August 2007, available at: http://www.sequence-

inc.com/index.php?option=com content\&task=view\&id=43\&Itemid $=22$ (last visited 5 June 2008); R. Romano, 'The Sarbanes-Oxley Act and the Making of Quack Corporate Governance', (2005) 114 Yale L. J. 1521-1611 (noting that the Federal Government's legislative initiative leading up to the 2002 Sarbanes-Oxley Act encroached upon the States' competence in corporate law making, calling the Act "not just a considerable change in law, but also a departure in the mode of regulation. The federal regime had until then consisted primarily of disclosure requirements rather than substantive corporate governance mandates, which were traditionally left to state corporate law.” (id., at 1523); see also H. T. Hollister, "Shock Therapy' for Aktiengesellschaften: Can the SarbanesOxley Certification Requirements Transform German Corporate Culture, Practice and Prospects?' (2005) 25 Nw. J. Int'l L. \& Bus. 453-484, 463: “... corporate-governance regulation in the 1930's was a matter of state, not national law, so the SEC's task for both U.S. and foreign corporations was one of requiring financial reports, rather than mandating governance structures.”

${ }^{136}$ In most U.S. corporate law jurisdictions, the directors of a corporation have the competence to determine the amount of compensation for managers, see 
who inside of the firm gets to determine CEO pay packages and how can investors (and, the firm) be protected against management's self-dealing. Apart from these substantive issues, however, lies a formal one. The formal issue is concerned with how executive compensation is regulated, in other words, whether the regulation of executive compensation ought to be assumed by the government or whether it could be left to private ordering.

A case in point for this development is the legislation introducing disclosure obligations for German stock corporations adopted in 2005. ${ }^{137}$ This legislation is particularly interesting when seen in light of the ongoing corporate governance reforms in Germany on the one hand and the initiatives in this regard from the Commission. While Germany is currently undergoing what is without doubt the most comprehensive overhaul of company and securities law reform in decades ${ }^{138}$, the dynamics of this process can only adequately be assessed in light of the greater discussions about the pressure on "Germany Inc" in a globally integrated market environment where investor confidence is key to gaining

137 See the GESETZ ÜBER DIE OFFENLEGUNG DER VORSTANDSVERGÜTUNGEN [VorstOG] (Federal CEO Earnings Disclosure Act) of August 3, 2005, published in: BundESGESETZBLATT [BGBl] (Federal Gazette) 2005 Vol. I, p. 2267 (available at: http://www.bmj.bund.de/files/-/1382/VorstOG.pdf (last visited 5 June 2008); for the draft and the ensuing discussion, see Bundesministerium der Justiz (Federal Ministry of Justice), Press release, 11 March 2005, Eckpunkte eines Gesetzentwurfs “Individulisierte Offenlegung der Gehälter von Vorstandsmitgliedern von Aktiengesellschaften” vorgestellt, available online at:

http://www.bmj.de/enid/0,0/Presse/Pressemitteilungen_58.html?druck=1\&presseartikel_i $\underline{\mathrm{d}=1906}$ (last visited 5 June 2008); see also „Grüne bemängeln Gesetzentwurf...”, NeTZEITUNG, 11 March 2005 (citing the critique voiced by members of the Green Party (Die Grünen) targeting the option for the general shareholder assembly adopting a nondisclosure possibility for management earnings with a $3 / 4$ majority).

138 For recent overviews, see U. Noack/D. Zetzsche, 'Corporate Governance in Germany: The Second Decade, Center for Business \& Corporate Law (CBC) Research Paper Series', (2005) CBC WP No. 0010 [http://ssrn.com/abstract=646761]; P. C. Leyens, 'German Company Law: Recent Developments and Future Challenges', (2005) 6 German L. J. 1407-1408; U. Noack/D. A. Zetzsche, 'Germany's Corporate and Financial Law 2007: (Getting) Ready for Competition', (2007) CBC-RPS No. 0028

[http://ssrn.com/abstract=986357] (highlighting the current dynamism of 'serviceoriented law making and innovative reforms') 
access to capital from large institutional investors. ${ }^{139}$ It is necessary to understand the particular quality of contemporary law reform in corporate governance in order to fully grasp the regulatory options available to the participants. As we shall see, this regulatory field is neither purely public nor private in nature. The intricate interaction between the government, a semi-public, semi-private expert commission, and industry representatives in a far-reaching public debate over mandatory vs. voluntary disclosure of CEO earnings, which we will describe in the following, leads us to the thesis that, rather than having the possibility to decide clearly in favour or against mandatory (or, voluntary) disclosure, the outcome of the struggle depends in reality on a complex and even unpredictable set of developments taking place in a volatile and hybrid regulatory environment. This means that rather than being a straight-forward example of either a radically decentralized and de-hierarchised law making enterprise or a top-down, government-made legal regime, the particular development of law making in Germany in this area illustrates the absence of clear-cut solutions. As has already become clear from the preceding section concerning the contested legal nature of corporate governance codes, the regulation of CEO compensation disclosure in Germany turns out to be a further illustration of an intricate intertwining of public and private ordering.

Executive compensation came onto the German corporate law reform agenda mainly under the pressure of an international, globe-spanning discussion over excessive CEO pay packages, management self-dealing, underscoring the investor's ultimate powerlessness to effectively constrain fraudulent and otherwise illicit behavior among managers. As such, executive compensation is yet another example of an issue that emerges in a particular regulatory, political and cultural context, but attains allegedly universal contours when entering a common debate among academics and policy makers around the world. As has become clear in the ongoing discussion over the convergence and divergence of different corporate governance models, many issues (such as outside directors and auditors, takeovers or regulatory competition), which had once been remembered in

139 J. W. Cioffi, 'Corporate Governance Reform, Regulatory Politics, and the Foundations of Finance Capitalism in the United States and Germany', (2005) 01 CLPE Research Paper Series (www.comparativeresearch.net) 
the concrete context in which they originated ${ }^{140}$, have come to occupy our minds as unavoidable challenges for law-makers and regulatory theory worldwide. $^{141}$ In order, however, to understand how a corporate governance idea, principle or theory enters into an existing regulatory framework and paradigm, we need to shed light on this paradigm in its greater embeddedness rather than treating it simply as an autonomous, isolated tabula rasa, just waiting to be filled with strange words. ${ }^{142}$

The notion of embeddedness, however, is certainly anything but easy to concretize. Against the background of contemporary revivals and reassessments of Karl Polanyi's seminal work on the "evolution of the 'market pattern'. ${ }^{143}$ What has been triggering the recently reawakened interest in Polanyi is the still unsatisfactory analysis and realization of the concept of embeddedness. It is thus no surprise that economic sociologists ${ }^{144}$ and corporate law scholars with a distinct interest in the

${ }^{140}$ R. J. Gilson, 'The Political Ecology of Takeovers: Thoughts on Harmonizing the European Corporate Governance Environment', in K. J. Hopt and E. Wymeersch (eds.), European Takeovers. Law and Practice (Butterworths, 1992); J. C. Coffee Jr., 'The Future as History: The Prospects of Global Convergence in Corporate Governance and Its Implications', (1999) 93 Nw. U. L. Rev. 641-707; D. Charny, 'Competition among Jurisdictions in Formulating Corporate Rules: An American Perspective on the "Race to the Bottom" in the European Communities', (1991) 32 Harvard International Law Journal (Harv. Int'l L.J.) 423-456

141 See the critique hereto by D. M. Branson, 'The Very Uncertain Prospect of 'Global' Convergence in Corporate Governance', (2001) 34 Corn. Int'l L. J. 321-362

${ }^{142}$ Hereto, see, e.g., H. T. Hollister, "Shock Therapy' for Aktiengesellschaften: Can the Sarbanes-Oxley Certification Requirements Transform German Corporate Culture, Practice and Prospects?' (2005) 25 Nw. J. Int'l L. \& Bus. 453-484, with regard to the certification requirements for foreign private issuers created by the Sarbanes-Oxley Act. See id., at 463: "An examination of basic German corporate structure, practices and values provides crucial context for the German objections to the certification requirements."

\footnotetext{
${ }^{143}$ K. Polanyi, The Great Transformation. The Political and Economic Origins of our Time (Beacon Press, 1944), 56-67, 57: "The market pattern [...] is capable of creating a specific institution, namely the market. Ultimately, that is why the control of the economic system by the market is of overwhelming consequence to the whole organization of society: it means no less than the running of society as an adjunct to the market.”

${ }^{144}$ J. Beckert, 'The Great Transformation of Embeddedness. Karl Polanyi and the New Economic Sociology', (2007) Max-Planck-Institut für Gesellschaftsforschung/Max-
} 
embedding factor of 'culture, 145 emphasize the need of taking a closer look at the way in which the notion of embeddedness can help assess the contemporary dynamics between formal and informal rule making. Above all, this research, itself developing against the background of a longstanding interest in 'social norms, ${ }^{146}$, points to the distinct challenges arising in the area of comparative legal research where the analytical lens is not wide enough to capture the complex structure of such 'semiautonomous' fields, as they are emerging along functionally differentiated, organizational and regulatory areas.

The "shocks" that have been hitting German ${ }^{147}$ and European ${ }^{148}$ corporate governance and that by many accounts demand a no less than radical reform of existing laws ${ }^{149}$, appear in a different light when perceived from a regulatory perspective. In this regard, executive compensation becomes an example of how top-down law making approaches alternate, interact and intertwine with attempts to promote corporate self-regulation, non-

Planck-Institute for the Study of Societies, MPIfG Discussion Paper 07/1 ; see already M. Granovetter, 'Economic Action and Social Structure: The Problem of Embeddedness', (1985) 91 American Journal of Sociology 481-510; M. Granovetter, 'The Impact of Social Structure on Economic Outcomes', (2005) 19 J. Econ. Persp. 33-50

${ }^{145}$ A. N. Licht/C. Goldschmidt/S. H. Schwartz, 'Culture, Law, and Corporate Governance', (2005) 25 Int'l Rev. Law and Econ. 229-255 (taking issue with LLSV's reliance on 'legal families' to explain corporate governance divergences); A. N. Licht, 'Social Norms and the Law: A Social Institutional Approach', (2005) Working Paper http://ssrn.com/abstract=710621, 52: It should be clear that dynamic processes are always at work. Cultural value dimensions constitute the backbone of a constantly developing body of social norms."

${ }^{146}$ R. Ellickson, 'Of Coase and Cattle: Dispute Resolution Among Neighbors in Shasta County', (1986) 38 Stan. L. Rev. 623; L. Bernstein, 'Opting out of the Legal System: Extralegal Contractual Relations in the Diamond Industry', (1992) 21 J. Leg. Stud. 115157

147 See Hollister, "Shock Therapy" for Aktiengesellschaften: Can the Sarbanes-Oxley Certification Requirements Transform German Corporate Culture, Practice and Prospects?, 25 Nw. J INT’L L \& Bus 453 (2004)

${ }^{148}$ G. Hertig, 'Western Europe's Corporate Governance Dilemma', in T. Baums,K. J. Hopt and N. Horn (eds.), Corporations, Capital Markets and Business in the Law. Liber Amicorum Richard M. Buxbaum (Kluwer Law International, 2000), at 266.

149 T. Baums, 'Company Law Reform in Germany', (2003) 3 J. Corp. L. Stud. 181-189 
official norm setting and alternative law enforcement mechanisms. These choices between alternative regulatory instruments and the concrete evolution of public, private and hybrid public-private ordering are deeply embedded in a nation's political economy and regulatory environment. ${ }^{150}$ No assessment of their legal nature, their compatibility with an existing institutional and normative regulatory environment, up to questions of compliance and enforceability can be carried out without reference to a specific context. It should already have become clear that in emerging areas of transnational law making, these contexts can increasingly be deterritorialized. ${ }^{151}$ But, in many cases, our interest remains fixated on the emergence of new legal regimes out of existing normative infrastructures. Just as much specific consumer protection instruments might be influenced by acquired views on how a specific consumer protection philosophy should be developed and promoted within a specific political economy ${ }^{152}$, other emerging normative regimes show the same degree of embeddedness. Corporate governance codes, given their complex and in many ways still not entirely resolved legal nature, will have to be interpreted with at least a view to the particular legal and regulatory environment in which they were conceptualized and developed. "Corporate governance codes function within a given legal environment. The interaction with the legal system is a complex matter that differs considerably from state to state, both due to differences in the legal status of the codes, but also due to differences in the environing legal system.”"153

150 See most recently K. Ibata-Arens/J. Dierkes/D. Zorn, 'Guest Editors' Introduction: Theoretical Introduction to the Special Issue on the Embedded Enterprise', (2006) 7

Enterprise \& Society 1-18, at 2: "Embeddedness connotes the complex interrelatedness of actors within their social, political, and cultural environments.” Hereto, see also M. Granovetter, 'Economic Action and Social Structure: The Problem of Embeddedness', (1985) 91 American Journal of Sociology 481-510; P. Zumbansen, 'Varieties of Capitalism and the Learning Firm. Corporate Governance and Labor in the Context of Contemporary Developments in European and German Company Law [CLPE Research Paper No. 3/2007 and University of Cambridge, Centre for Business Research Working Paper 347, available at: http://ssrn.com/abstract=993910]', (2007) 8 Eur. Bus. Org. L. Rev. [EBOR] 467-496

151 See, supra, II.

152 See, e.g., G. Howells/T. Wilhelmsson, 'EC Consumer Law: Has it Come of Age?' (2003) 28 European Law Review 370-388.

153 E. Wymeersch, 'Enforcement of Corporate Governance Codes', (2005) ECGI Law Working Paper No. 46/2005, at 2 
Research by sociologists, lawyers, cultural psychologists and economic historians on evolution, path dependency and embeddedness suggests that the relationships between regulatory instruments and causal outcomes cannot adequately be captured by the use of dichotomies. Often-employed dichotomies include the state and the market ${ }^{154}$, markets and hierarchies ${ }^{155}$, public and private ${ }^{156}$ or, the firm and its environment. "Such dichotomies construct divisions between two opposing, mutually exclusive categories. Dichotomy formulations always involve a binary choice, which limits the ability to measure complexity." coincide with the critique put forward by legal sociologists and legal theorists against the use of dichotomies such as market vs. state, or public vs. private when assessing new regulatory structures in a transforming welfare state $^{158}$, but also contribute to and greatly enrich the work done by Varieties of Capitalism scholars referred to above. ${ }^{159}$ The lessons learned

154 See the brilliant critique by R. L. Hale, 'Coercion and Distribution in a Supposedly Non-Coercive State', (1923) 38 Political Science Quarterly 470-494.

155 O. Williamson, Markets and Hierarchies. Analysis and Antitrust Implications (Free Press, 1975); see hereto the critique by M. Granovetter, 'Economic Action and Social Structure: The Problem of Embeddedness', (1985) 91 American Journal of Sociology 481-510, 489-490 (critiquing Williamson for underestimating the role played by personal relations and obligations as well as institutional arrangements in encouraging trust and discouraging malfeasance); see the elaboration and expansion by J. Beckert, 'The Great Transformation of Embeddedness. Karl Polanyi and the New Economic Sociology', (2007) Max-Planck-Institut für Gesellschaftsforschung/Max-Planck-Institute for the Study of Societies, MPIfG Discussion Paper 07/1 .

156 A. C. Cutler, 'Artifice, Ideology and Paradox: the Public/Private Distinction in International Law', (1997) 4 Review of International Political Economy 261-285

157 K. Ibata-Arens/J. Dierkes/D. Zorn, 'Guest Editors' Introduction: Theoretical Introduction to the Special Issue on the Embedded Enterprise', (2006) 7 Enterprise \& Society 1-18, at 7

158 See, e.g., G. Frankenberg, 'Shifting Boundaries: The Private, the Public, and the Welfare State', in M. B. Katz and C. Sachße (eds.), The Mixed Economy of Social Welfare (Nomos, 1996); N. Fraser/L. Gordon, 'Dekodierung von "Abhängigkeit". Zur Genealogie eines Schlüsselbegriffs des amerikanischen Wohlfahrtsstaats', (1993) 26 KJ 306-323; P. Zumbansen, 'Quod Omnes Tangit: Globalization, Welfare Regimes and Entitlements', in E. Benvenisti and G. Nolte (eds.), The Welfare State, Globalization, and International Law (Springer, 2003), 147-149.

159 See, supra. 
so far from work done in employment ${ }^{160}$, corporate $^{161}$ and social welfare law $^{162}$ teach us about the embeddedness of regulatory regimes in historically grown cultural, political and economic institutions. As we expand the traditional Varieties of Capitalism lens to study the evolving nature of the identified liberal and coordinated market regimes ${ }^{163}$, in particular the shifting weights between political sides ${ }^{164}$ and the intricate and unpredictable interaction between public and private actors ${ }^{165}$, we can begin to grasp the challenge put before us through the cited examples of regulatory change. We are thus slowly beginning to reach beyond the historical origins of particular institutions, their alleged starting points and ensuing trajectories, lock-ins and aberrations ${ }^{166}$ to look more closely at the particular dynamics of regulatory change occurring both with regard to the institutions and the normative content that can be found to govern a particular field.

${ }^{160}$ K. Thelen, 'Varieties of Labor Politics in the Developed Democracies', in P. A. Hall and D. Soskice (eds.), Varieties of Capitalism (Oxford University Press, 2001)

161 J. W. Cioffi/S. S. Cohen, 'The state, law and corporate governance: the advantage of forwardness', in S. S. Cohen and G. Boyd (eds.), Corporate Governance and Globalization. Long Range Planning Issues (Edward Elgar, 2000)

162 P. Manow, 'Welfare State Building and Coordinated Capitalism in Japan and Germany', in W. Streeck and K. Yamamura (eds.), The Origins of Nonliberal Capitalism (Cornell University Press, 2001)

163 On this distinction, see foremost P. A. Hall/D. Soskice, 'An Introduction to Varieties of Capitalism', in P. A. Hall and D. Soskice (eds.), Varieties of Capitalism. The

Institutional Foundations of Comparative Advantage (Oxford University Press, 2001)

164 J. W. Cioffi, 'Corporate Governance Reform, Regulatory Politics, and the Foundations of Finance Capitalism in the United States and Germany', (2006) 7 German L. J. 533-562

165 P. Zumbansen, 'The Parallel Worlds of Corporate Governance and Labor Law', (2006) 13 Indiana Journal of Global Studies 261-312

166 M. J. Roe, 'Chaos and Evolution in Law and Economics', (1996) 109 Harv. L. Rev. 641-668 


\section{The Political Economy of Corporate Governance REFORM IN GERMANY}

\section{GOVERNING 'GERMANY INC.’}

For the longest time, the governing norm for executive compensation in German stock corporations has been sec. 87 (1) Aktiengesetz (Stock Corporation Act). It reads:

"In setting up the total earnings for each member of the Management Board (Salary, Profit participation, Compensation, Insurances, Provisions and auxiliary remunerations of any type), the Supervisory Board must ensure that the total earnings remain appropriate in relation to the tasks of the Manager and the state of the company. This correspondingly is true also of retirement pay, payments to heirs and related payments." 167

The norm's most prominent and governing features are both its explicitness and implicitness. The law demands that the remuneration of members of a stock corporation's executive, or managing board must be appropriate (angemessen) to the tasks of the board member and to the situation of the company (Lage der Gesellschaft). That is its explicitness. The implicitness of the norm can be seen in its silence as regards further specification and substantiation of this appropriateness. While much discussion has taken place with regard to the level of appropriateness in executive pay, this has been comparatively been less than elsewhere. Largely responsible for the comparative acquiescence of the wider public in what German managers earn might be attributed to a simultaneous awareness that the German Vorstandssprecher and Vorstandsmitglieder

167 German original: Der Aufsichtsrat hat bei der Festsetzung der Gesamtbezüge des einzelnen Vorstandsmitglieds (Gehalt, Gewinnbeteiligungen, Aufwandsentschädigungen, Versicherungsentgelte, Provisionen und Nebenleistungen jeder Art) dafür zu sorgen, daß die Gesamtbezüge in einem angemessenen Verhältnis zu den Aufgaben des Vorstandsmitglieds und zur Lage der Gesellschaft stehen. Dies gilt sinngemäß für Ruhegehalt, Hinterbliebenenbezüge und Leistungen verwandter Art. [my translation, PZ] 
(CEOs and managers) generally earn strikingly less than their peers in New York or Los Angeles. ${ }^{168}$

While in Germany, as in elsewhere, financial scandals in recent years have led to public concern about excessive management pay ${ }^{169}$, law making activity in the last two years has remarkably focused less on substance than on procedure, in particular on the rules governing disclosure of management earnings. German stock corporations are obliged under sec. 285 No. 9 Handelsgesetzbuch (Commercial Code) to identify in their annual report the collective sum of compensation earned by the collectivity, be it the board of managers or the supervisory council. While this obligation extends to different categories of remuneration - salary, boni and options - it used to stop short of demanding disclosure of individual earnings of board members.

In the meantime, following the installation of the Corporate Governance Code Commission under the Chairmanship of Gerhard Cromme in $2001^{170}$, which had presented a Code in February 2002, some advance was made towards pushing German industry to disclose individualized corporate earnings. In the aftermath, however, policy makers, industry leaders and lobbyists disagreed about the need to comply with the Code's

168 Finfacts Ireland, 30 March 2006: Global Executive Pay 2006; Senior executives in the US earn the highest salaries, http://www.finfacts.com/irelandbusinessnews/publish/article_10005367.shtml; Jay W. Lorsch, 'Rising CEO Pay: What Directors Should Do', Harvard Business School Working Knowledge, 13 August 2006, http://hbswk.hbs.edu/item/5490.html: “Ask any thoughtful corporate board member what they are most concerned about these days, and it is not Sarbanes-Oxley. It is CEO pay.” (last visited 5 June 2008)

169 Ulrich Papendick, Welche Konzernchefs zuviel verdienen [which corporate bosses earn too much, transl. PZ], MANAGER MAGAZIN, 23 June 2005, available at:

http://www.managermagazin.de/unternehmen/vorstandsgehaelter/0,2828,361510,00.html (last visited 5 June 2008); Europa Vergleich: Deutsche Bosse verdienen zu viel [European comparison: German bosses earn too much], DER SPIEGEL, 23 June 2006, available at: http://www.spiegel.de/wirtschaft/0,1518,422959,00.html (last visited 5 June 2008).

${ }^{170}$ Effective 30 June 2008, the chairmanship will be transferred, see Press Release of 5 June 2008, http://www.corporate-governance-code.de/eng/download/Presseinfo-BMJWechse-Kodex-Kommission_en.pdf. 
recommendations. ${ }^{171}$ A legislative proposal introduced by the Ministry of Justice in March 2005 changed this state of ambivalence. ${ }^{172}$ According to the new provisions, which came into force on 1 January 2006, companies are obliged to disclose detailed management earnings. ${ }^{173}$ This constituted a dramatic change to the prior regime under sec. 285 No. 9 Handelsgesetzbuch. Yet, the real degree to which the new legislation departs from the old state of the law can only be discerned when appreciated against the background of the political and regulatory climate that prevailed before and after the introduction of the new law. For this, we must again look to the proliferation of corporate governance codes generally and to the German example as a telling illustration: What became strikingly clear was that the introduction of self-introductory instruments in the area of company law did and continues to constitute a challenge to traditional understandings of legislative authority among German scholars. While there seems to be a wide-ranging consensus on the need to improve investor confidence, at the centre of which we find calls for greater corporate transparency, better accountability and a more effective corporate governance, much of which is endorsed in the recommendations and suggestions of the German Corporate Governance Code, the concerns about its still not fully resolved constitutional status on the one hand and questions of voluntary compliance on the other continue to be problematic. The story of the Corporate Earnings Disclosure Law of 2005 is a most telling illustration of this ambiguity. To cite again the

${ }^{171}$ Last amended version (14 June 2007), http://www.corporate-governancecode.de/eng/download/E_Kodex 2007 markiert.pdf. But see the Press Release of the Commission of 18 April 2008, stating that level of compliance has been increasingly steadily: http://www.corporate-governancecode.de/eng/download/080418_Pressemitteilung_2008_en.pdf (last visited 5 June 2008)

${ }^{172}$ Federal Minister of Justice, Brigitte Zypries, justified the regulatory advance with the failure of companies to voluntarily disclose their management earnings. See 'Corporate Governance: Zypries fordert gläserne Vorstandsgehälter’, Manager-Magazin 14 May 2005, http://www.managermagazin.de/unternehmen/vorstandsgehaelter/0,2828,299768,00.html (last visited 5 June 2008)

173 See Gesetz über die Offenlegung der Vorstandsvergütungen [Law Concerning the Disclosure of Management Earnings] of 3 August 2005, published in BuNDESGESETZBLATT [Federal Gazette] 2005, Vol. I, p. 2267, available at: http://www.publicgovernance.de/pdf/vorstog_aug_05.pdf (last visited 5 June 2008) 
Justice Minister in her speech of November 2004 relating to the draft legislation: "The Principle of societal self-regulation lies at the roots of the success of corporate governance. Rightfully this principle has received international support and many followers." ${ }^{174}$ She went on to highlight the reasons why her government should at this time not pursue the adoption of a public act instead of continuing to find further voluntary support for the Corporate Governance Code's recommendation to disclose individual earnings, declaring that she thinks that "also in this area norms included in the Code are better than rigid statutory laws. Because especially in this sensible field voluntary changes of heart and self-regulation are more advantageous than state coercion. That is why we prefer - against many other voices - the economy's self-regulation through a flexible recommendation of the Code. From our point of view, therefore there is no need to pass a statutory law regulating the disclosure of corporate earnings."175

The mood, however, changed within a matter of months. In fact, already in summer 2004, the Minister had underscored her commitment to industry self-regulation, emphasizing simultaneously, however, that she would pursue a legislative solution by mid-2005, if industry bosses proved resilient towards the Code's recommendations. ${ }^{176}$ Much of this drive for

174 “Das Prinzip der gesellschaftlichen Selbstregulierung begründet den Erfolg von Corporate Governance. Dieses Prinzip hat zu Recht auch international Anerkennung erhalten und zahlreiche Anhänger gefunden.” [My translation from the German, PZ]

175 See id., supra. "Allerdings halte ich auch in diesem Bereich Regelungen im Rahmen des Kodex für besser als rigide gesetzliche Vorschriften. Denn gerade auch auf diesem sensiblen Feld sind freiwilliges Umdenken und Selbstregulierung vorteilhafter als staatlicher Zwang. Daher bevorzuge ich - trotz vieler anderer Stimmen - weiterhin die Selbstregulierung der Wirtschaft über eine flexible Kodexvorgabe. Es besteht deshalb aus meiner Sicht kein Anlass, die Offenlegungspflicht bereits jetzt nach so kurzer Zeit gesetzlich zu normieren.” [My translation from the German, PZ].

${ }^{176}$ Politik erhöht Druck auf Unternehmen zur Offenlegung der Manager-Bezüge, NeTZEITUNG.DE, 2 August 2004, available at: http://www.netzeitung.de/wirtschaft/wirtschaftspolitik/298430.html (last visited 5 June 2008); see also Wendelin Wiedeking (CEO, Porsche), "Wie man das Thema auch wendet, es kommt immer Unsinn heraus”[Regardless from which perspective you look at the issue, it always turns out to be nonsense, our translation], in: FRANKFURTER Allgemeine Zeitung, No. 64, 17 March 2005. 
this change of mind, however, turned out to come from a place where only few would have expected it. None other than the chairman of the first Corporate Governance Commission of 2001, which had prepared not only the most comprehensive task list for the company law legislator in the post-War era, but also had called in its final report for the installation of a second commission mandated to draft the Corporate Governance Code ${ }^{177}$, Professor Theodor Baums, had become the leading voice for a statutory regulation of corporate earnings disclosure. In many weeks of lobbying in early 2005, Professor Baums scathed German industry leaders to comply with the recommendations of the Code to disclose their earnings in an individualized form: "Concerning an obligation to disclose corporate earnings, the Code postulates this already today. Unfortunately, however, there is a consensus among approximately two-thirds of all DAX corporations not to follow these recommendations of the Code. In our view, this constitutes a veritable abuse of that instrument. And it is for this reason that the Federal Justice Minister is rightfully threatening with a statutory obligation. The EU Commission holds a similar view." "178

\section{THE HybridizATION OF LAW MAKING: THE RETURN OF THE STATE?}

Read this in light of the euphoric declarations regarding the value of a newly discovered ability of the German economy to modernize itself through the means of self-regulation ${ }^{179}$, and the fragility of the

177 T. Baums, 'Interview: Reforming German Corporate Governance: Inside a Law Making Process of a very new nature', (2001) 2 German Law Journal at: http://www.germanlawjournal.com/past_issues.php?id=43

178 Andreas Nölting, Von gierigen Vorständen und albernen Vergleichen (Interview with Theodor Baums), MANAGER MAGAZIN, 26 April 2004, available at: http://www.managermagazin.de/unternehmen/vorstandsgehaelter/0,2828,305446-3,00.html (last visited 5 June 2008). See id., "Was die Offenlegungspflicht angeht, so besteht sie nach dem Kodex schon heute. Es gibt aber leider eine Übereinstimmung von etwa zwei Drittel der DaxUnternehmen darüber, dass man sich an diese Empfehlungen des CorporateGovernance-Kodex nicht hält. Das ist meines Erachtens ein klarer Missbrauch dieses Instruments. Und das bedeutet, dass die Bundesjustizministerin Recht hat mit ihrer Drohung, dass wir eine gesetzliche Vorgabe haben müssen. Die EU-Kommission sieht das ähnlich.” [My translation, PZ]

179 See, supra, III B 2 
embeddedness of corporate and industry self-regulation is in the larger regulatory culture. To speak, like Professor Baums did in the cited interview, of an 'abuse' of the Code by companies mutually agreeing not to provide an individualized disclosure of their management compensation schemes, surely turns the idea of self-regulation on its head. This is even more remarkable as Professor Baums himself highlighted the innovative and reform potential of self-regulation, which he studied with his commission between 2000 and 2001, before submitting his final report to the German government in July 2001. ${ }^{180}$ Likewise, the Justice Minister highlighted the success of corporate self-regulation through Corporate Governance Codes, referring specifically to the recently revised Corporate Governance Principles drafted by the OECD. ${ }^{181}$

The regulatory origin and scope of the recent German legislation is of particular interest in that it underlines the above-suggested hybridisation of the norms governing this field. While the Ministry makes it very clear that it deems earnings disclosure of management to be of vital importance for rebuilding and strengthening international investor confidence in German firms, the draft foresees the possibility for the shareholder assembly to vote against disclosure with a $3 / 4$ majority. ${ }^{182}$ Certainly, while this has met with criticism, this option powerfully underscores the political dilemma the legislator is facing in this area. Given the stern and outspoken resistance of influential industry leaders in the past months against an obligation to disclose management earnings, the option clause seems a well-reasoned compromise. But, with regard to the perspective taken here on the changing shape of reforming a fast evolving and highly sensitive area such as company law, the larger questions lie elsewhere. The remuneration dispute is but the tip of the iceberg of the longstanding

180 T. Baums, 'Interview: Reforming German Corporate Governance: Inside a Law Making Process of a very new nature', (2001) 2 German Law Journal at: http://www.germanlawjournal.com/past_issues.php?id=43

181 Federal Minister of Justice, Brigitte Zypries, Speech before the Annual Handelsblatt Conference, 18 November 2004

182 See GESETZ ÜBER DIE OFFENLEGUNG DER VORSTANDSVERGÜTUNGEN [VorstOG] (Federal CEO Earnings Disclosure Act) of August 3, 2005, published in: BundesGesetzBLAtT [BGBl] (Federal Gazette) 2005 Vol. I, p. 2267 (available at: http://www.publicgovernance.de/pdf/vorstog_aug_05.pdf, Art. 1 (2), inserting a new para. 5 to s. 286 Aktiengesetz [Stock Corporation Law] 
struggle over adequate ways of valuating the firm and, with it, a richer assessment of what is at stake in the current shareholder value debate. Clearly, Ferrarini, Moloney and Vespro are right in their assertion that "It is easier to find problems than solutions in this field."183

\section{CONCLUSION}

A very important element in the making of border-crossing corporate governance regimes is their specific emergence through soft-law, often issued and disseminated by non-state actors such as international organizations, associations or private corporations. While this paper highlighted the particular dynamics through which the 'juridical touchdown' will sometimes occur with domestic governments initiating legislative projects to enhance, further ground or to enforce the soft norms of corporate self-regulation, the lesson to be learned consists in sensibilising us to the intricate interwoven character of private and public regulation in this context. One the one hand, much of the law making developments in this area could not be imagined without the push coming from non-state actors, issuing and disseminating codes of conduct, recommendations and norms for the global market place. On the other hand, however, the German case study illustrated the particular, deeply embedded regulatory dynamics of norm-creation in a much contested area. As corporate governance scholarship continues to sharpen its lens for deeper structures of formal/informal norm-creation and the particular socio-economic cultures ${ }^{184}$ in which different hybrid regulatory approaches emerge, it becomes evident to which degree 'comparative corporate governance ${ }^{185}$ is being transformed in a multi-disciplinary area of regulatory analysis. Our focus on the way in which corporate

${ }^{183}$ G. Ferrarini/N. Moloney/C. Vespro, 'Executive Compensation in the EU: Comparative Law and Practice', (2003) ECGI Working Paper Series in Law, WP No. 09/2003 , at 66 .

${ }^{184}$ See only A. N. Licht, 'The Mother of all Path-Dependencies: Towards a CrossCultural Theory of Corporate Governance Systems', (2001) 26 Delaware Journal of Corporate Law 147-205.

${ }^{185}$ M. J. Roe, 'Comparative corporate governance', in P. Newman (eds.), The New Palgrave Dictionary of Economics and the Law (Palgrave Macmillan, 1998) 
governance principles are received by and simultaneously are shaping different national political economies sharpens our perceptions for the existing differences in countries' corporate laws, but even more so for the specific ways in which soft law becomes intertwined, changed, adapted and interwoven within a regulatory environment which itself is no longer stable. To cite, once again, the German example: the major corporate reform of 1998, the so-called Transparency and Control Legislation ${ }^{186}$, did begin a lengthy process of national soul-searching into the governing principles of a set of company law rules, the scope and content of which had for some time already ceased to be a merely domestic concern, but had instead become part of a transnational debate over 'good corporate governance'. While domestic politicians, scholars and lobbyists would engage in deliberating over every detail of German corporate governance ${ }^{187}$, the issues being discussed, the proposals on the table and the problem awareness among the law reformers were of veritable transnational nature, emerging from parallel reform efforts in other countries, among private and non-state actors around the world and the public at large. In that sense ${ }^{188}$, domestic company law reform can clearly be seen as part of an emerging transnational legal pluralism. Its defining feature is the continuing contestation of the very distinction on which legal pluralism would be conceived to rest upon to begin with: the distinction between law and non-law.

As has become clear, corporate governance norms offer themselves as a telling example of the transformation of traditional state-originating, official norm-setting in favour of increasingly de-centralized, multi-level processes of norm production. At the same time, not only are norms produced on more levels; the nature of these norms themselves changes

${ }^{186}$ Hereto, see, e.g., J. W. Cioffi, 'Restructuring "Germany Inc.": The Politics of Corporate Governance Reform in Germany and the European Union', (2002) 24 Law \& Policy 355-402.

187 See the brilliant illustration provided by M. Höpner, 'European Corporate Governance Reform and the German Party Paradox', in: Max-Planck-Institut für Gesellschaftsforschung, available at: http://www.mpi-fg-

koeln.mpg.de/pu/mpifg_dp/dp03-4.pdf

${ }^{188}$ Referring to examples of transnational human rights litigation, see hereto R. Wai, 'Transnational Private Law and Private Ordering in Contested Global Society', (2005) 46 Harv. Int'l L.J. 471-486, 475-476. 
dramatically. What our assessment of the present trajectories of ECGR and the case study of Germany so far have illuminated is the changing nature of regulating business in globally interdependent markets, suggesting nothing less than a far-reaching erosion of boundaries between state and non-state actors, official and unofficial law, public and private ordering. ${ }^{189}$

189 See e.g. V. Gessner/R. P. Appelbaum/W. F. Felstiner, 'Introduction: The Legal Culture of Global Business Transactions', in V. Gessner,R. P. Appelbaum and W. F. Felstiner (eds.), Rules and Networks: The Legal Culture of Global Business Transactions (Hart Publishing, 2001); Francis Snyder, Economic Globalisation and the Law in the $21^{\text {st }}$ Century, in: The Blackwell Companion to Law and Society (2003); K. Pistor, 'Of Legal Transplants, Legal Irritants, and Economic Development', in P. Cornelius and B. Kogut (eds.), Corporate Governance and Capital Flows in a Global Economy (Oxford University Press, 2003). 